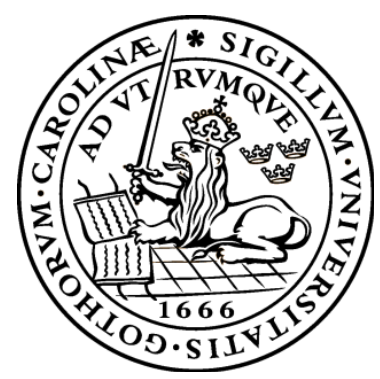

Lund University

School of Economics and Management

Department of Business Law

\title{
THE PREFERRED TREATMENT OF THE FIXED ESTABLISHMENT IN THE
} EUROPEAN VAT

by

\section{Rasa Mikutienè}

HARN60 Master Thesis

Master's Programme in European and International Tax Law

$2013 / 2014$

Spring semester 2014

2 June 2014

Supervisor: Professor Ben J. M. Terra

Examiner: Associate Professor Oskar Henkow

Author's contact information:

E-mail: Rasa.Mikutiene@gmail.com

Tel.: +37069999711 


\section{TABLE OF CONTENTS}

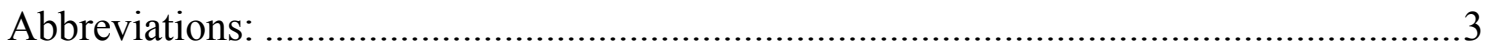

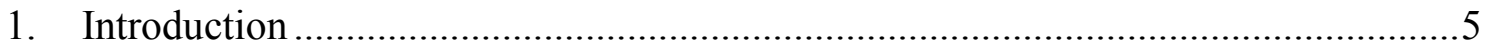

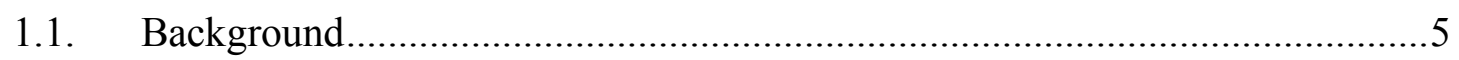

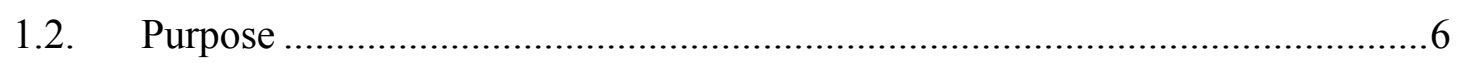

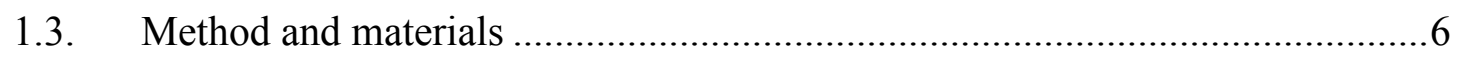

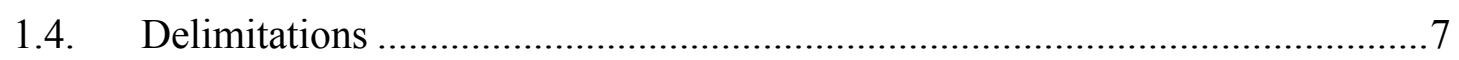

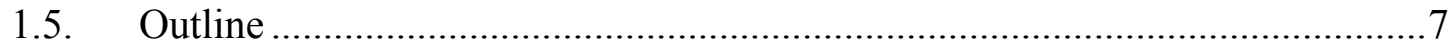

2. The purpose of the FE and its role in the common EU VAT system....................... 7

2.1. Taxation at the place of the actual consumption and the role of the FE............7

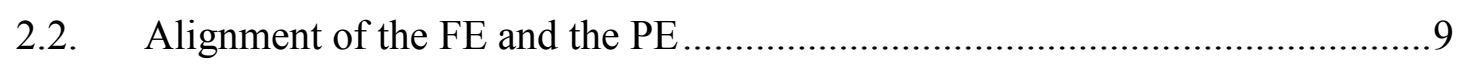

3. Creation of the active FE and attribution of supplies thereto............................... 10

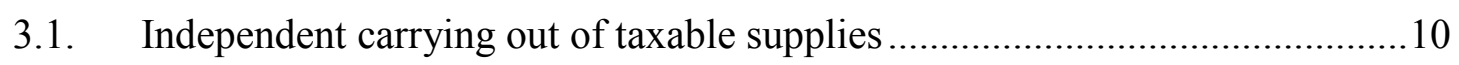

3.1.1. Carrying out of taxable supplies ....................................................... 10

3.1.1.1. Actual engagement in the supply .................................................. 10

3.1.1.2. Functions inherent in the supply ................................................... 11

3.1.1.3. Functions performed during or after the supply ..............................12

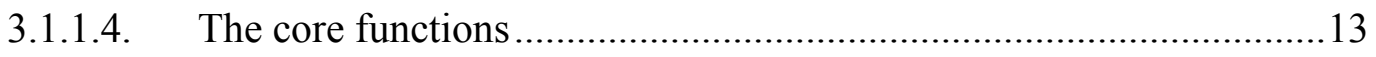

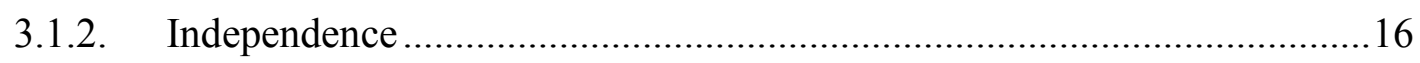

3.2. The possession of a suitable structure of human and technical resources.......17

3.2.1. Human and/or technical resources....................................................... 17

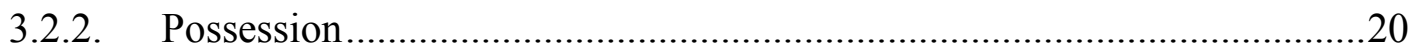

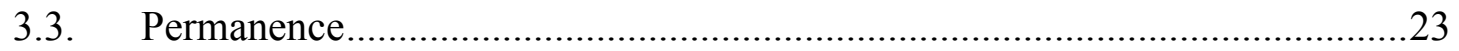

4. Creation of the passive $\mathrm{FE}$ and attribution of acquisitions thereto .........................25

4.1. Independent existence of the passive FE ....................................................25

4.1.1. Ability to use the services for its own needs .........................................25

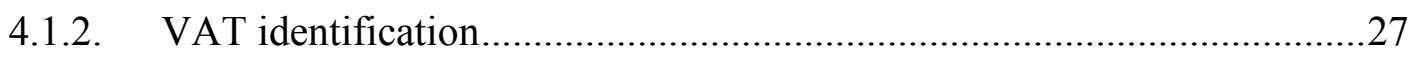

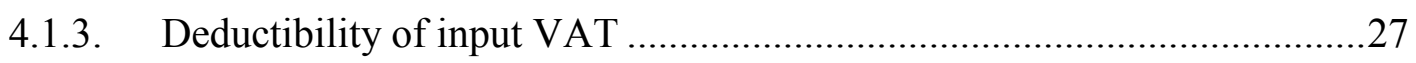

4.2. Attribution of acquisitions to the customer's FE and mitigation of tax

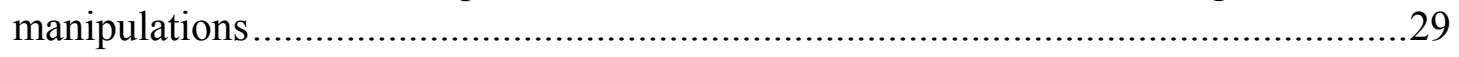

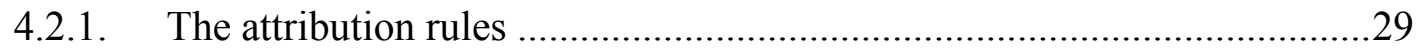

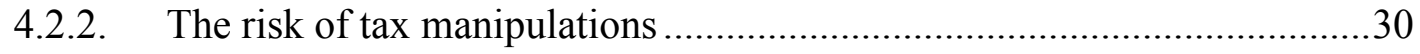

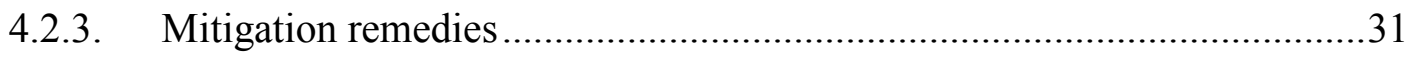

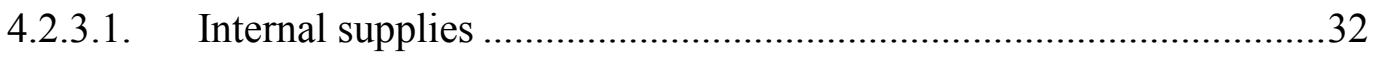

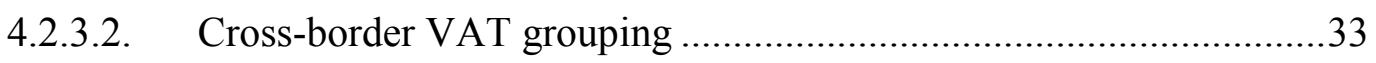

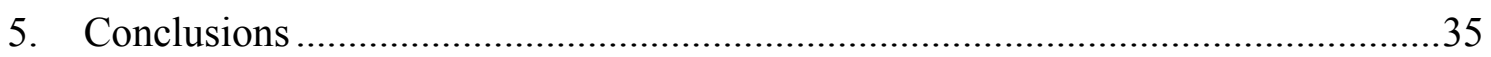

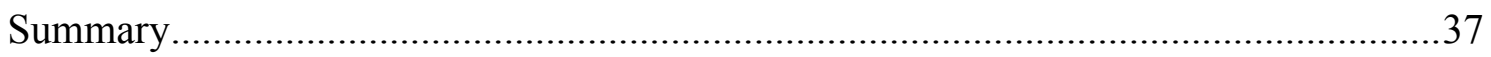

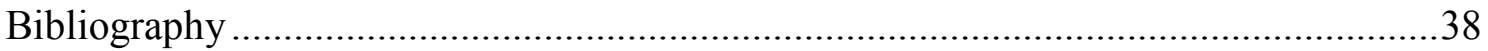




\section{Abbreviations:}

13th Directive - Thirteenth Council Directive 86/560/EEC of 17 November 1986 on the harmonization of the laws of the Member States relating to turnover taxes Arrangements for the refund of value added tax to taxable persons not established in Community territory

Active FE - FE engaged in supplies of services, otherwise the supplier's FE, the supplying FE

AG - Advocate General

B2B supplies - supplies to taxable persons

B2C supplies - supplies to non-taxable persons (consumers)

BEPS Action Plan - Plan on Base Erosion and Profit Shifting of the OECD of 19 July 2013

Customer - purchaser of the services, either a taxable person or a non-taxable person (consumer)

Directive 2008/8/EC - Council Directive 2008/8/EC of 12 February 2008 amending Directive 2006/112/EC as regards the place of supply of services

Directive 2008/9/EC - Council Directive 2008/9/EC of 12 February 2008 laying down detailed rules for the refund of value added tax, provided for in Directive 2006/112/EC, to taxable persons not established in the Member State of refund but established in another Member State

CoJ - the Court of Justice and the Court of Justice of the European Communities (until 1 December 2009)

EU - European Union

Implementing Regulation - Council Implementing Regulation No 282/2011 of 15 March 2011 laying down implementing measures for Directive 2006/112/EC on the common system of value added tax

OCED Convention - OECD Model Tax Convention on Income and on Capital, otherwise OECD Convention

OECD Commentary - OECD Commentary to the OECD Convention

MOSS - the "Mini One Stop Shop" mechanism that is currently applicable to supplies of electronic services to non-taxable persons established in the EU by the suppliers not established in the EU and that will be expanded to supplies of telecommunication, television and radio broadcasting and electronic services to non-taxable persons irrespective of where the supplier is established as of 1 January 2015

MS - the Member States

OECD - Organisation for Economic Cooperation and Development

Passive FE - FE engaged in acquisitions of services, otherwise the customer's FE, the purchasing FE

$\mathbf{P E}$ - permanent establishment in direct taxation

Principal business establishment - the place where a taxable person has established his business for the purposes of inter alia Articles 44 and 45 of the VAT Directive 
Refund Directives - Directive 2008/9/EC and the $13^{\text {th }}$ Directive.

$\mathbf{T P}$ - transfer pricing

UK - the United Kingdom of Great Britain and Northern Ireland

VAT - value added tax

VAT Committee - an advisory Committee set up under Article 398 of the VAT Directive to promote uniform application of the provisions of the VAT Directive by inter alia examining the questions related to the application of the VAT legislation raised by the Commission of the EU or the MS and adopting the non-binding guidelines on the examined issues

VAT Directive - Council Directive 2006/112/EC of 28 November 2006 on the common system of value added tax 


\section{Introduction}

\subsection{Background}

In the EU VAT the place of supply of services should reflect the principle of taxation at the place where the actual consumption of the services takes place. ${ }^{1}$ This principle is reflected in the place of supply rules that in most of the cases differ for B2B and B2C supplies. ${ }^{2}$

Under the main rule the place of supply ${ }^{3}$ of services in B2B supplies is the place where the customer has established his principal business establishment or FE if the services are supplied to this FE and it is located in a country other than where the principal business establishment is located. ${ }^{4}$ This rule is believed to reflect the principle of taxation at the place of the actual consumption as businesses are deemed to use the acquired services in their economic activities in the place where their business is established and include the costs of the acquired services in the price of the goods and services they further supply to their customers. ${ }^{5}$ In the absence of the principal business establishment or the FE, the reference is made in the general rule to the permanent address or usual residence of the customer. ${ }^{6}$ In B2B supplies the customer has to account VAT in the country of respectively his principal business establishment or FE as the reverse charge mechanism is applied, unless the supplier makes the supply through his establishment located in the country where the place of supply of the respective service is (in this case VAT is accounted in a standard way). ${ }^{7}$ Respectively, the role of the FE of both the supplier (i.e. the active FE) and the customer (i.e. the passive FE) is of importance from two perspectives: (i) the MS's entitlement to tax the supply depends on whether the service is supplied to the principal business establishment or the FE of the customer, if any; and (ii) the negative and positive effects on the cash flows of both the customer and the state in which the supply takes place depends on whether the supplier has the active FE in the place of the supply as that determines the application of the reverse-charge mechanism.

In B2C supplies the place of supply was not shifted to the location of the customer due to the administrative simplicity and thus it does not necessarily coincide with the actual place of consumption. Under the general rule supplies of services are taxable at the place where the supplier has established his principal business establishment or FE if the services are supplied from this FE and it is located in a country other than where the principal business establishment is located. ${ }^{8}$ In the absence of the principal business

\footnotetext{
${ }^{1}$ Recital 3 of the Directive 2008/8/EC.

${ }^{2}$ For the supplies of services definition of the business customer is expanded to non-taxable persons who are identified for VAT purposes and to persons who are engaged in both taxable and non-taxable activities (i.e. for all their acquisitions they are considered as business customers), see Article 43 of the VAT Directive.

${ }^{3}$ Although the biggest attention in this thesis is paid to the general place of supply rules that are mainly related to the use of the FE, it should be mentioned that the FE of the supplier is also referred to in Article 56(2) of the VAT Directive (long-term hiring of pleasure boats to non-taxable persons), Article 58 of the VAT Directive (electronic services) and Article 307 of the VAT Directive (travel agents' services) In addition, under Articles 38-39 of the VAT Directive FE is relevant for the place of taxation of supplies of gas, electricity, heat and cooling energy.

${ }^{4}$ Article 44 of the VAT Directive.

5 Ben J.M. Terra, The VAT Package and Anti-Tax Fraud Measures (Lund University School of Economics and Management, 2009), 64.

${ }^{6}$ Article 44 of the VAT Directive.

${ }^{7}$ Articles $192 \mathrm{a}$ and 196 of the VAT Directive.

${ }^{8}$ Article 45 of the VAT Directive.
} 
establishment or the FE, the reference is made to the permanent address or usual residence of the supplier. ${ }^{9}$ For B2C supplies the reverse charge mechanism is normally non-applicable, meaning that VAT is accounted by the supplier. Respectively, the role of the FE is important from the perspective of entitlement of the MS to tax the supplies of services and to get the revenue from taxation as deduction of the VAT is not likely.

Although, as illustrated above, in the determination of the place of supply of services and obligation to account VAT the FE plays an important role in the EU VAT, this concept is far from being clear. No definition of the FE is provided in the VAT Directive. Only the Implementing Regulation provides the definitions of the active and passive FE. The FE is defined as any establishment, characterised by a sufficient degree of permanence and a suitable structure in terms of human and technical resources to enable it to provide the services which it supplies (for the active FE) or to receive and use the services supplied to it for its own needs (for the passive FE). ${ }^{10}$ These definitions, however, merely cite CoJ's judgment in Berkholz case, the first ever in the field, and for the practical application are too abstract. ${ }^{11} \mathrm{CoJ}$ has had a few more occasions after Berkholz to examine the issues related to the existence of the FE. However, these judgments were issued under the specific factual circumstances and, being rather casuistic, do not create comprehensive rules of a general nature. Therefore, national practices of the MS with respect to the application of the FE concept differ significantly.

\subsection{Purpose}

Taking into account the role of the FE as discussed in Section 1.1, a lack of clarity of when the FE is deemed to be created and when its existence affects the place of supply and VAT accounting obligations creates legal uncertainty for the taxpayers as tax administrators often act as having a wide discretion in deciding whether the FE exists in a particular situation. In the contrary, the lack of clarity creates a field for manipulations by the taxpayers on the place of taxation and VAT accounting obligations as they can channel acquisitions of services through the FEs located in the foreign jurisdictions providing a more favourable VAT treatment of the supplies.

Respectively, the purpose of this thesis is twofold: first, to find the preferred treatment of the FE in the EU VAT stemming from the interpretation of the current legislative provisions and CoJ's practice and, second, to suggest measures for mitigation of the negative effects of channelling of the acquisitions.

\subsection{Method and materials}

In achieving the purpose of this thesis, the traditional legal dogmatic method will be used. The main objects of the analysis will be the binding and non-binding provisions of the legislation, including the current one, as well as pending coming into force and expired. In addition, the CoJ's practice and various doctrinal debates on the topic will be analysed. National legislation will be taken into account in certain situations to illustrate the existence of the diverging national systems and to reveal their positive and negative features for the purpose of finding the preferred treatment of the concept. Furthermore, OECD's documents, including the proposals, will be analysed to compare the FE with the PE in direct taxation. Literal, contextual, teleological and historical methods of interpretation will be used in the analysis of the previously mentioned sources.

\footnotetext{
${ }^{9}$ Article 45 of the VAT Directive.

${ }^{10}$ Articles 11 and 53 of the Implementing Regulation.

${ }^{11}$ Judgment in Berkholz, 168/84, EU:C:1985:299, para. 19.
} 


\subsection{Delimitations}

It is assumed that the reader of the thesis has the background knowledge of the EU VAT and thus limited background information about the concepts discussed herein will be provided.

In order to concentrate directly on the accomplishment of the purpose of the thesis, such issues as the determination of the status of the customer, the location of the permanent address or usual residence of the supplier or the customer and the establishments of the non-taxable person will not be addressed herein. Furthermore, it is not within the scope of the thesis to provide a comprehensive analysis of all the place of supply rules for services or to discuss all the potential schemes of channelling of the acquisitions of the services through the FEs or other related tax saving schemes.

Moreover, although the internal supplies of services and the VAT grouping will be suggested as the measures for combating the undesired channelling of acquisitions, it is not within the purpose of this thesis, due to its limited compass and wide nature of the said concepts, to provide a comprehensive analysis thereof.

\subsection{Outline}

Following the purpose of this thesis, in Section 2 thereof the purpose of the FE and its place in the common VAT system, as well as alignment of the FE and the PE will be discussed to provide a background for the discussion on the preferred treatment of the concept. In Section 3, the criteria related to the creation of the active FE and the attribution of supplies thereto will be analysed. Issues related to the existence of the passive FE will be discussed in Section 4. This section will also address the complicated issue of attribution of supplies to the customer's FE and the resulting possibilities for VAT manipulations. Mechanisms to be used mitigating the manipulations will be suggested in Section 4 as well. Conclusions will be made in Section 5.

\section{The purpose of the FE and its role in the common EU VAT system}

\subsection{Taxation at the place of the actual consumption and the role of the $F E$}

As it was indicated in the Introduction, the place of supply of services should reflect the principle of taxation at the place where the actual consumption of the services takes place. However, it is often rather hard to determine where the place of the actual consumption is. ${ }^{12}$ Thus enshrining of this principle in the form of the place of supply rule in the VAT Directive was seen by the EU legislator as too burdensome from the administrative point of view and, in addition, as creating too much of legal uncertainty for the taxpayers. ${ }^{13}$ Therefore, the place of supply rules that are deemed to reflect the place of the actual consumption to the greatest possible extent were created. ${ }^{14}$

\footnotetext{
${ }^{12}$ Thomas Ecker, 'Place of Effective Use and Enjoyment of Services - EU History Repeats Itself' (2012) November/December International VAT Monitor, 407-408; EC Consultation Paper VAT - The Place of Supply of Services to Non-Taxable Persons, 2005, p. 2

$<$ http://ec.europa.eu/taxation_customs/resources/documents/vat_place_of_supply en.pdf $>$ accessed 13 May 2014.

${ }^{13}$ Ben J.M. Terra, The VAT Package and Anti-fraud Tax Measures (n 5) 93; Ad van Doesum, Herman van Kesteren, Gert-Jan van Norden and Irene Reiniers, 'The New Rules on the Place of Supply of Services in Eropean VAT' (2008) 2008-2 EC Tax Review, 78.

${ }^{14}$ EC Consultation Paper VAT - The Place of Supply of Services to Non-Taxable Persons, 2005 (n 12) p. 3.
} 
The establishment of either the supplier or the customer represent the deemed place of consumption where the general place of supply rules are applied. ${ }^{15}$ This place, however, does not necessarily coincide with the actual place of consumption of a particular service in a particular situation. ${ }^{16}$ The place of establishment is merely a proxy created due to the fact that it is impractical to determine every time the actual place of consumption.

As the supplier and the customer might have not only the primary business establishment but also the secondary establishment, it was logical to foresee in the rules that the place of taxation shifts to the location of the secondary establishment (the FE) that is supplying or receiving the service in question. However, in the same way as the primary business establishment, the FE represents only the deemed place of consumption and cannot be aligned with the place of the actual consumption. In other words, reference to the location of the FE cannot be understood as requiring determination of where the actual consumption of the service takes place. ${ }^{17}$ Otherwise, the distinction between the principle of taxation at the place of the actual consumption and the place of supply rules indicating only the deemed place of consumption would be lost. This is confirmed by the two other concepts present in the EU VAT system: the principal business establishment as a primary point of reference and the use and enjoyment override rule.

It is an established practice of the CoJ that, even where the FE exists, reference to it is to be made in determining the place of supply only when referring to the principal business establishment would lead to irrational result or would create a conflict with another MS. ${ }^{18}$ Thus, the FE is only a secondary point of reference to be used only in certain situations. ${ }^{19}$ The CoJ has not explained what it considers being a rational result. ${ }^{20}$ Logically it should be the reflection of the principle of taxation at the place of the actual consumption applied in the light of the principle of administrative simplicity. However, taxation at the location of the secondary establishment does not necessarily mean that the service will be taxed at the place where it is actually consumed. ${ }^{21}$ Thus, the FE cannot be aligned with the place of consumption. Otherwise, the secondary reference in the place of supply rules would have been made not to the FE but to the place of the

\footnotetext{
${ }^{15}$ Special place of supply rules applicable to certain types of services are set in Articles 46-50, 52 and 5459. The special rules were created for these services because they can better reflect the principle of taxation at the place of the actual consumption and, at the same time, referring to that place will not be too cumbersome, see recital 6 of the Directive 2008/8/EC.

${ }^{16}$ Thomas Ecker, 'Place of Effective Use and Enjoyment of Services - EU History Repeats Itself' (n 12) 409.

${ }^{17}$ Thomas Ecker, 'Place of Effective Use and Enjoyment of Services - EU History Repeats Itself' (n 12) 408.

18 Judgment in Berkholz, EU:C:1985:299, para. 17; Judgment in DFDS, C-260/95, EU:C:1997:77, para. 19; Judgment in Lease Plan, C-390/96, EU:C:1998:206, para. 24; Judgment in ARO Lease, C-190/95, EU:C:1997:374, para. 15.

19 There are opinions that this rule does not apply after the place of supply rules were changed as of 1 January 2010, see Ben J.M. Terra and Julie Kajus, A Guide to the European VAT Directives, Volume 1, Introduction to European VAT (IBFD 2013), Section 11.4.2. For the contrary opinion see Madeleine Merkx, Establishments in EU VAT (Kluwer Law International 2013) 82.

${ }^{20}$ It is admitted by several authors that so far the CoJ refused taxation at the place of the deemed FE only when the result would have been non taxation of the supply in the EU, see Ben J.M. Terra and Julie Kajus, A Guide to the European VAT Directives, Volume 1, Introduction to European VAT (n 19) Section 11.4.2.1. However, in these cases the CoJ also considered that no FE was created at all so avoiding reference solely to the principle of the primary point of reference; see to that effect Ben Terra and Peter Wattel, European Tax Law (Kluwer Law International 2012), 188.

${ }^{21}$ Madeleine Merkx, Establishments in EU VAT (n 19) 82-83.
} 
actual consumption. Reference to the latter was, however, only made in the rule of the use and enjoyment override that is only applicable in specific situations relating to third countries.

Pursuant to Articles 59a and 59b of the VAT Directive the purpose of the use and enjoyment override rule is to tax certain supplies in the EU although based on the place of supply rules these supplies fall outside of the scope of EU VAT, provided that the effective use and enjoyment of the service takes place in the EU or vice versa. List of the supplies to which the use and enjoyment override rule can be applied contains, among others, the general place of supply rules that refer to the FE. Respectively, it is to be applied even in situations where the reference to the FE does not ensure taxation at the actual place of consumption.

Based on the aforesaid, the EU VAT should not go to the direction where the concept of the FE, which is used in the place of supply rules as a proxy in order to ensure the legal certainty when determining the place of supply, is as wide as the principle of taxation at the place of the actual consumption as this was clearly not the intention of the legislator. Respectively, a conclusion on existence of the FE should be made following strict criteria ensuring that the concept will not be unduly expanded and taxable persons will be provided with the sufficient legal certainty.

\subsection{Alignment of the $\mathrm{FE}$ and the $\mathrm{PE}$}

Although the CoJ expressly stated in its judgment in FCE case that OECD Commentary is of no relevance in the field of $\mathrm{VAT}^{22}$, many authors have expressed their opinion that it would be more practical to have one single concept applicable in the field of both direct and indirect taxation. ${ }^{23}$ Although the concepts have some similarities as they both are secondary establishments for taxation purposes, they cannot be aligned because of the very different nature of the direct and indirect taxes and the different role of the FE if compared to the PE.

Firstly, VAT is a consumption tax aiming at taxing consumption of services and it should be levied at the place where the actual consumption of each separate service takes place (where the place of the actual consumption is difficult to be determined, other proxies must be used for the administrative simplification). Direct taxes are taxes on income and should be levied in the place where the business processes generate surpluses. ${ }^{24}$ Secondly, VAT is levied on transaction-by-transaction basis and taxable amount cannot be spread towards and taxed in several jurisdictions, meaning that each supply has to be attributed to one concrete establishment. ${ }^{25}$ Meanwhile in direct taxation surpluses generated through the taxable year can be spread towards the several establishments that contributed to generating the surpluses. ${ }^{26}$

Respectively, for VAT purposes there is a need to determine one establishment that is most related to the supply (as is discussed in Section 3) and attribute the supply to this

\footnotetext{
${ }^{22}$ Case FCE, C-210/04, EU:C:2006:196, para. 39.

23 E.g. Pasquale Pistone, 'Fixed Establishment and Permanent Establishment' [1999] May/June VAT Monitor, 106.

${ }^{24}$ Michaele Iavagnilio, 'Concepts of Permanent and Fixed Establishments under Italian Law - the Philip Morris Case' [2002] November/December VAT Monitor, 471.

${ }^{25}$ When the place of supply rule refers to the supplier's establishment, e.g. the general rule for B2C supplies. See Madeleine Merkx, Establishments in European VAT (n 19) 82.

${ }^{26}$ Marcin Gorazda and David Elvira Benito, 'Destination Principle in Intra-Community Services and the "Fixed Establishment" in the VAT. A Comparative Study of Polish and Spanish Law' [2014] Volume 42, Issue 2 Intertax, 123.
} 
establishment. In the contrary, for direct taxes all the establishments related to the activity or the supply need to be determined and profits proportionately attributed to them. Thus, the nexus for the creation of the PE is naturally rather different from the FE. Therefore, while separate aspects of the FE and the PE (such as the link with a particular jurisdiction, the necessity of certain resources, permanence etc.) can be compared, especially in the light of the lack of relevant explanations in the field of VAT, alignment of the concepts is not desired.

\section{Creation of the active FE and attribution of supplies thereto}

The main difficulty lying in the attribution of the supplies to one of the establishments of the supplier is the existence of the FE that is far from being easy to determine for the supplier himself. Failure by the supplier to make the proper determination may lead to taxation in a place other than where the intended place of taxation is under the place of supply rules or even to the double taxation. For example, in B2B situation where the supplier treats that he has no FE in the customer's jurisdiction, the head office will issue the invoice with no VAT and the customer will account for VAT under the reverse charge. If, however, the tax administrator of the customer's jurisdiction considers that the supplier has the FE, the supplier might be required to pay the output VAT on this supply and it is doubtful whether he would be able to get this VAT from the customer who already accounted VAT under the reverse charge. ${ }^{27}$

Pursuant to the Implementing Regulation and the CoJ's practice, the active FE may be created when the supplier permanently possesses a suitable structure of human and technical resources ${ }^{28}$ enabling him to carry out taxable supplies independently ${ }^{29}$. Criteria deriving from this definition are discussed in the following Sections.

\subsection{Independent carrying out of taxable supplies}

\subsubsection{Carrying out of taxable supplies}

\subsubsection{Actual engagement in the supply}

As it was discussed in Section 1.1, the role of the active FE is to shift the place of taxation to another jurisdiction in $\mathrm{B} 2 \mathrm{C}$ supplies or to influence the application of the reverse charge in B2B supplies. Logically, the FE can play the said roles only when it is actually engaged in the supplies. ${ }^{30}$ The mere presence of resources enabling the supplies to be made is not sufficient for the FE to be created.

The previously mentioned conclusion stems from Articles 11(2) and 53(1) of the Implementing Regulation. ${ }^{31}$ It is said in the former one that the resources need to enable

\footnotetext{
27 The commercial agreement may not always enable the supplier to claim additional amounts from the customer. In such a case the supplier would have to bear the burden of VAT himself. The only relief the supplier can expect is that amount charged to the customer would then be considered not as a taxable amount (without VAT) but as the price already with VAT (following the principle that the VAT burden should fall on the customer), see Judgment in Tulica and Plavosin, Joined Cases C-247/12 and C-250/12, EU:C:2013:256, paras 35 and 44 of the judgment.

28 Judgment in Berkholz, EU:C:1985:299, para. 18, and Articles 11 and 53 of the Implementing Regulation.

${ }^{29}$ Judgment in ARO Lease, EU:C:1997:374, para. 19.

${ }^{30}$ The same view is shared by Joep Swinkels who considers the active FE being an extension of its head office abroad and, in addition, that the CoJ abandoned the suggestion of the Commission of the EU expressed in the proposal for a Nineteenth Directive to treat as a FE any fixed installation of a taxable person, even if no taxable transactions can be carried out there, see 'Fixed Establishments and VATSaving Schemes’ [2006] November/December International VAT Monitor, 416.

${ }^{31}$ Which define the FE for the purposes of respectively the place of supply and the application of the reverse charge mechanism.
} 
to provide the services that the FE supplies, meanwhile the latter mentions resources enabling the FE to make the supply in which it intervenes. Thus, both Articles refer to the actual making or intervention in the supply and not the mere possession of the resources. Since definitions in both Articles are in essence the same analysis on the functions of the active FE for the purposes of the place of supply and for the purposes of application of the reverse charge will be made jointly. ${ }^{32}$

It must, however, be mentioned that some ambiguity on the actual engagement is created by the Refund Directives. They contain analogous conditions that the applicant shall not have a FE from which business transactions are effected in the MS of refund during the period of refund. ${ }^{33}$ This can be taken as an indication that the FE may exist for the purposes of the VAT Directive without being engaged in any business transactions. However, considering that the Refund Directives form part of the common EU VAT system, it should be held that they refer to the same FE and the same its capacities as referred to in the VAT Directive. The engagement is mentioned additionally solely with the purpose of better illustrating that the Refund Directives cannot be applied where the supplier makes the output supplies in the MS of refund (through the establishment or otherwise) as then he can enjoy the right to deduction instead of the refund. This does not mean, however, that the presence and the capacity of the secondary establishment for the purposes of the VAT Directive and the Refund Directives are different.

The Commission of the EU has recently stated in its opinion to the VAT Committee that the resources of the FE should be actually used for the purposes of the given supply or their use has to be specifically provided for in the contract. ${ }^{34}$ The former statement is in line with the Implementing Regulation and confirms the conclusion made herein. However, the latter condition does not stem either from the legislation or from the practice of the CoJ. Application of this condition in practice would be rather formalistic and would create space for wide tax manipulations. ${ }^{35}$

\subsubsection{Functions inherent in the supply}

Article 11(2) of the Implementing Regulation does not explain what is understood as making of the supply. Pursuant to Paragraph 2 of Article 53(2) of the Implementing Regulation, the FE exists and intervenes in the supply for the purposes of the application of the reverse charge when its resources are used in performing the transactions inherent in the fulfilment of the taxable supply.

When all the functions inherent in and even somehow related to a particular supply are performed exceptionally from one establishment of the supplier, determination of the place of supply or application of the reverse charge becomes rather clear. For example, the CoJ said in its judgment in ARO Lease that provision of a lease service consists of negotiating, drawing-up, signing and administering agreements and making the leased

\footnotetext{
32 The same approach is followed by the UK tax authorities, see to that effect Peter Schilling and Deirdre Hogan, 'Intervention - a Problematic New Concept in EU VAT Law' [2010] May/June International VAT Monitor, 190.

${ }^{33}$ Article 3 of the Directive 2008/9/EC and Article 1(1) of the 13th Directive.

${ }^{34}$ VAT Committee Working Paper No 791 Concerning the Application of EU VAT Provisions of 15 January 2014, 5.

${ }^{35}$ The same approach is followed by the UK tax authorities that are of the opinion that the actual economic situation (economic substance and reality) and not contractual obligations must be taken into account, see HM Revenue and Customs guidance No VATPOSS 05100 $<$ http://www.hmrc.gov.uk/manuals/vatpossmanual/vatposs05100.htm> accessed on 30 May 2014.
} 
vehicles available to the customers. ${ }^{36}$ If all these functions are performed by one particular establishment located in a place other than where the principal business establishment is located, the FE would likely be created and the supply would be attributed thereto. ${ }^{37}$

However, suppliers often spread activities inherent in and related to one supply among the different establishments. In direct taxation it would normally lead to the attribution of the portions of profits to the different establishments that were involved in deriving the profits. However, in VAT each supply needs to be attributed to only one establishment that is making the supply and taxable amount cannot be spread over several establishments. ${ }^{38}$ Therefore, it becomes necessary to determine which functions are to be treated as inherent in the supply and, where they are spread among the several establishments, which of them are prerequisite and thus performance thereof means that this establishment is actually making the supply.

\subsubsection{Functions performed during or after the supply}

It is said in Paragraph 1 of Article 53(2) of the Implementing Regulation that the FE is considered to intervene in the supply if its resources are used for the transactions inherent in the fulfilment of the taxable supply made before or during the fulfilment. Thus, for the purposes of attribution of the supply to one of the establishments only functions that are performed before or during the supply but not after the supply are relevant. In the light of this, the guideline of the VAT Committee stating that the establishment is to be considered as intervening in the supply where it performs certain subsequent actions, e.g. after-sales services or application of guarantee clauses, seems not to be in line with the Implementing Regulation. ${ }^{39}$ It would be irrational for the aftersales services to influence the place of supply and application of the reverse charge where the main functions related to the supply are performed not by the FE responsible for the after-sales functions. Furthermore, VAT has to be accounted at the time of the supply and thus linking the chargeability with the actions that will be performed sometime in the future, if at all performed, would encumber the functioning of the VAT system and lower the level of legal certainty for the suppliers and their customers. ${ }^{40}$

Which functions inherent in the supply are performed before, during or after the supply has to be determined on transaction-by-transaction basis and will differ depending on the type of the service. Taking as an example leasing service, functions inherent in the supply should be sorted as follows. ${ }^{41}$ Negotiation, drawing-up and signing of the agreements should be attributed to the functions that are inherent in the supply and performed before its fulfilment, making of the vehicles available to the customers during the fulfilment of the supply. Meanwhile administering of the agreements might contain many different actions and thus might be attributed to any of the three stages, e.g. collection of customer's claims, collection of cars after termination of the agreement etc. are actions performed after the supply and should be irrelevant for the purposes of the FE. ${ }^{42}$

\footnotetext{
${ }^{36}$ Judgment in ARO Lease, EU:C:1997:374, para. 18.

${ }^{37}$ Provided that other requirements for the creation of the FE be met.

${ }^{38}$ Madeleine Merkx, Establishments in European VAT (n 19) 82.

${ }^{39}$ Guidelines adopted at the 86th meeting of the VAT Committee on 18-19 March 2009.

${ }^{40}$ Article 63 of the VAT Directive.

${ }^{41}$ As listed by the CoJ in the Judgment in ARO Lease, EU:C:1997:374, para 18.

${ }^{42}$ For the purposes of the PE these functions would be relevant and would require attribution of the respective part of the profit to the PE engaged in these functions, provided that they would not be treated as ancillary ones, see Commentary of Article 5 of the OECD Convention.
} 
Paragraph 2 of Article 53(2) of the Implementing Regulation also clarifies that administrative support tasks such as accounting, invoicing and collection of debt-claims are not relevant for the FE purposes. As the VAT Committee correctly explains with this respect, these actions are related merely to enforcement of legal and accounting obligations related to but not inherent in the transaction. ${ }^{43}$

\subsubsection{The core functions}

The EU legislation does not provide additional explanations on which of the functions performed before or during the fulfilment of the supply are prerequisite or core for the attribution of the supply to a particular establishment. That is especially relevant when they are spread among the several establishments. Some guidance can be found in the CoJ's practice.

\section{(a) $\mathrm{DFDS}$}

The first case in which the CoJ explicitly reflected upon the functions an establishment should engage in to qualify as the FE was $D F D S .{ }^{44}$ It should be said at the outset that the $\mathrm{CoJ}$ did not list the functions that are prerequisite for the FE to be created. However, its arguments in this judgment will serve as a starting point for the analysis of the later judgments.

In this case the question was related to whether DFDS-UK, being a $100 \%$ owned subsidiary of DFDS-DK, created the latter's FE in the UK when it acted as an exclusive sales agent. DFDS-DK acted as inter alia a tour operator and thus its services were limited to bundling of several tourism related services and resale of packages to the customers. DFDS-UK was authorised to represent DFDS-DK in supplying tour packages to the UK based customers and had to perform the following functions: market and advertise the services and promote the commercial image of DFDS, make available the qualified sales and operational personnel, make the reservations of the trips and accommodation by accessing the DFDS-DK's central computer, accept the payments, provide the customers with the requisite documentation issued in the name of DFDS-DK and handle customer's claims. ${ }^{45}$ As it can be seen, DFDS-UK had to perform functions before, during and after the fulfilment of the supply (i.e. making available of the packages).

The CoJ made the general conclusion in its judgment that DFDS-DK was supplying services to the UK clients through its FE created by DFDS-UK. It did not explain, however, which of the listed functions were predominant for such a conclusion to be made. It can only be said now in the light of the provisions of the Implementing Regulation that after sales activities, such as dealing with passengers' complaints, should not be prerequisite in an analogous situation for the purposes of the creation of the FE.

\section{(b) ARO Lease}

Some five months after the judgment in $D F D S$, the CoJ issued its judgment in $A R O$ Lease case. ${ }^{46}$ In this case the applicant was ARO Lease, a company established in the Netherlands, which leased vehicles to inter alia Belgian customers. The analysis of the $\mathrm{CoJ}$ was focused on two main aspects: (i) the fact that the Belgian customers were

\footnotetext{
${ }^{43}$ Guidelines adopted at the 86th meeting of the VAT Committee (n 39).

44 Judgment in DFDS, EU:C:1997:77. Peculiarities related to the fact that DFDS-UK was a separate legal entity will be discussed in Section 3.2 .

${ }^{45}$ Opinion of AG La Pergola in DFDS, C-260/95, EU:C:1997:20, paras 3-4.

${ }^{46}$ Judgment in ARO Lease, EU:C:1997:374.
} 
brought into contact with the lessor through the independent self-employed persons (agents that were engaged in marketing of the services); and (ii) that the cars to be leased were bought from the Belgian car dealers and were stored at their premises on behalf of the lessor after the termination of the lease period (until the lessees decided whether to acquire the vehicles). ${ }^{47}$ The lease contracts were, however, concluded and functions related to making the cars available to the customers were performed directly by the lessor's staff present in the Netherlands. ${ }^{48}$

Although after the judgment in DFDS it was expected that the CoJ would treat ARO Lease having the FE in Belgium, the CoJ decided in the contrary. ${ }^{49}$ The CoJ listed the functions that are inherent in the supply of the lease service and as neither of these functions was performed in Belgium, no FE could have been created. ${ }^{50}$ This should be taken as a general conclusion that marketing activities are not relevant for the FE purposes as they are not among the functions performed before or during the fulfilment of the supply. ${ }^{51}$ As regards the leasing services in particular, the mere presence of the vehicles at the location of the customer does not influence creation of the FE if all the functions related to making them available to the customer are performed from a different location. ${ }^{52}$ Furthermore, the judgment suggests that the storage of the vehicles in the jurisdiction of the customer after the termination of the lease period is a special after-sales function that is irrelevant for the purposes of the FE.

(c) $R A L$

Further clarification on the functions that are inherent in the supply can be found in the AG's opinion in the $R A L$ case $^{53}$. RAL group was engaged in operating of slot gaming machines in the UK. Initially all the functions inherent in and related to the supply of the gaming services were performed by the UK based company RAL Ltd (RAL). However, in the end of 2000 RAL Group changed the structure of activities and spread the functions related to the supply between the several group companies. ${ }^{54}$

Under the new scheme RAL (Channel Islands) Ltd (CI) was formally engaged in the supply of the gaming services to the UK customers. The other three group companies performed the following functions. RAL Machines Ltd (Machines) owned the machines and related licenses and leased them to CI. RAL owned the premises, kept the licences for the operation of the gaming machines therein, and leased the premises to CI. Machines and RAL also took care of the maintenance of respectively the machines and

\footnotetext{
${ }^{47}$ Judgment in ARO Lease, EU:C:1997:374, para. 10.

48 These functions included buying of the vehicles from the dealers chosen by the customers and registration of the vehicles in Belgium in the name of the lessor.

${ }^{49}$ Ben J.M. Terra and Julie Kajus, Introduction to European VAT (n 19) Section 11.4.2.

${ }^{50}$ According to the CoJ, the lease service consists of negotiation, drawing-up and signing of agreements, making of the vehicles available to the customers and administering the agreements, see Judgment in ARO Lease, EU:C:1997:374, para. 18, and L. De Broe, 'Cross-border leasing of cars into Belgium: issues of VAT and the freedom to provide services - analysis of and comments on the European Court's holding in Aro Lease' [1997] 1997/4 EC Tax Review, 222.

${ }^{51}$ Except where the service supplied is marketing.

${ }^{52}$ Later on in Judgment in Lease Plan, EU:C:1998:206, para. 28, the CoJ confirmed that registration of the vehicles in the jurisdiction of the customer has no relevance for the creation of the FE.

${ }^{53}$ Opinion of AG Maduro in $R A L, \mathrm{C}-452 / 03$, EU:C:2005:65. The CoJ in this case did not analyse the existence of the FE although was asked to do so by the referring court. The CoJ considered that the services provided in the UK by CI that was established in Channel Islands (outside of the territorial scope of EU VAT) qualified as entertainment services. These services were subject to VAT in the place where they were physically carried out and thus the existence of the FE was irrelevant for the place of supply, see to that effect Judgment in RAL, EU:C:2005:289, para. 34.

${ }^{54}$ Opinion of AG Maduro in RAL, EU:C:2005:65, paras 2-4.
} 
the premises. RAL Services Ltd (Services) had the staff necessary for the performance of the day-to-day activities related to the supply of the gaming services and was contracted by $\mathrm{CI}$ for the performance of the following functions: provision of music, refreshments and change to the customers, emptying of cash boxes of the machines, witnessing large payouts, providing security, etc. Respectively, the activities of CI itself, as indicated AG Maduro in his opinion, solely confined to the accounting and monitoring of the cash flows from the machines. ${ }^{55}$

AG Maduro was of the opinion that neither Services nor other group companies had the direct involvement in the conclusion and performance of the contracts with the customers and solely performed the ancillary tasks in relation to the supply of the services. ${ }^{56}$ He believed that the contractual arrangements were made and implemented (i.e. gaming services provided) between the each customer and CI directly through the slot gaming machines. Respectively, as the machines were located in the UK, the functions inherent in the supply were carried out in the UK. Meanwhile the functions performed by the other group companies (as listed in the previous paragraph) in the UK and by the CI itself in the Channel Islands were called by the AG as the mere ancillary tasks and thus as being of no importance for the creation of the FE in the UK.

It can be concluded from this opinion, seeing it in the light of the previous CoJ judgments and the provisions of the VAT Directive and the Implementing Regulation, that the list of functions inherent in the supply and performed before or during the fulfilment that are relevant for creation of the FE can be narrowed down to the conclusion of agreements and performance of the core functions that are essential for the service to be at all supplied, or, in other words, the functions that best reflect the very essence of the service. ${ }^{57}$ Meanwhile other functions, although normally inherent in and related to the full-scale service, should be disregarded for the purposes of existence of the FE and attribution of the supply thereto. ${ }^{58}$

Whether the prerequisite importance should be granted to the conclusion of the agreement or the performance of the functions forming the core of the service remains not clarified in the legislation or by the CoJ is. Due to the lack of such guidance, national legislation of the MS is rather different with this respect. For example, Belgium and France consider that the FE intervenes in the supply if it takes part in negotiating the contract between the supplier and the customer, irrespective of who actually performs the core functions inherent in the supply of a particular service. ${ }^{59}$ Meanwhile in the UK and Germany it is considered that the supply is made by the establishment most closely connected to the supply (i.e. performing the core functions related to the provision of the service) irrespective of who concludes the contract with the customer. ${ }^{60}$ Considering the role of the FE in the field of supply of services and the fact that VAT is a tax on supplies and not on contracts, the UK's and Germany's approach should be followed and the substantial importance should be given to the performance of the core

\footnotetext{
${ }^{55}$ Opinion of AG Maduro in RAL, EU:C:2005:65, para. 54.

${ }^{56}$ Opinion of AG Maduro in RAL, EU:C:2005:65, para. 51.

${ }^{57}$ The same view is shared by Ben J.M. Terra and Peter Wattel, European Tax Law, 189.

${ }^{58}$ Pursuant to AG Maduro for the gaming service to be supplied payout to the customer is not an essential part of the service. Only the action of gaming itself in a rather narrow sense is the core element of the supply of this type of service and thus relevant for the creation of the FE.

${ }_{59}$ Peter Schilling and Deirdre Hogan, 'Intervention - A Problematic New Concept in EU VAT Law' (n 32) 190.

${ }^{60}$ See to that effect Peter Schilling and Deirdre Hogan, 'Intervention - A Problematic New Concept in EU VAT Law' (n 32) 191; Madeleine Merkx, Establishments in European VAT (n 19) 86.
} 
functions inherent in the supply and not to such a formal element as the conclusion of agreements. ${ }^{61}$

\subsubsection{Independence}

In its judgment in ARO Lease case the CoJ said for the first time that the FE must possess a sufficient degree of permanence and a structure adequate, in terms of human and technical resources, to supply services on an independent basis. In this judgment the $\mathrm{CoJ}$ did not provide any explanation of the independence criteria. Considering the conclusion on the functions the FE needs to perform made in Section 3.1.1, it can be concluded that the independence requirement is related to the FE concluding agreements and performing the core functions inherent in the supply on its own, using its own resources and issuing autonomous decisions with this respect ${ }^{62}$ or, in other words, without assistance of the other parts of the business. ${ }^{63}$ Otherwise, it could not be concluded that the FE supplies the service.

This independence should not be aligned with the independence referred to in Article 9 of the VAT Directive that is applicable when determining whether an individual person is at all engaged in the economic activities for the purposes of VAT and that, pursuant to Article 10 of the VAT Directive, excludes employees from the field of application of VAT. As is confirmed by DFDS case, even persons meeting the independence requirement of Article 9 of the VAT Directive (i.e. engaged in economic activities) might create the FE for another taxable person. ${ }^{64}$ In such a case their activities in acting as the FE should meet the independence requirement deriving from ARO Lease.

Independence referred to in Article 9 of the VAT Directive was also referred to by the $\mathrm{CoJ}$ in $F C E$ case when analysing whether the supplies between the head office and the FE should be subject to VAT. In this context it was relevant whether the FE is independent from the head office in the sense that it carries out independent economic activities. As the FE was treated as being engaged in the economic activities of its head office, it did not meet the independence criteria (i.e. was not engaged in independent economic activities) and thus could not acquire services from the head office as a separate taxable person. The main criteria used by the CoJ in deciding whether the branch carries out the independent economic activities was whether the branch bears the economic risks associated with the activities it is engaged in. ${ }^{65}$ If these risks are not born, the branch is merely an extension of the head office and performs economic activities thereof.

It must be noted that in the situation where the $\mathrm{FE}$ is created in a foreign jurisdiction because of using the resources provided by the third party that is engaged in the independent economic activities, the transposition of the FCE outcome is not that straightforward. ${ }^{66}$ Although the third party provides the supplier with the resources that

\footnotetext{
${ }^{61}$ Madeleine Merkx treats conclusion of agreement as an auxiliary function as it does not have the effect of the FE taking part in the supply of a service, see 'Fixed Establishments and VAT Liabilities under EU VAT - Between Delusion and Reality' [2012] January/February International VAT Monitor, 24-25.

${ }^{62}$ See to that effect Ben J.M. Terra and Julie Kajus, Introduction to European VAT (n 19) Section 11.4.2.1.

${ }^{63}$ Madeleine Merkx, Establishments in European VAT (n 19) 76.

${ }^{64}$ Madeleine Merkx, Establishments in European VAT (n 19) 80; Ben J.M. Terra and Julie Kajus, Introduction to European VAT (n 19) Section 11.4.2.1.

${ }^{65}$ Judgment in FCE, EU:C:2006:196, para. 35.

${ }^{66}$ The applicant in Welmory case was afraid of the same person being treated at the same time as the supplier and the purchaser of the services supplied under the cooperation agreement as Welmory-PL was
} 
create the latter's FE, it is also engaged in its separate economic activities. In this case not all transactions between the supplier and the third party must be disregarded for VAT purposes. Supplies effected between the supplier and the third party acting as an independent taxable person engaged in its independent economic activities should not be disregarded. Meanwhile supplies between the supplier and its FE, because the FE is merely an extension of its head office abroad, should fall outside of the scope of VAT. Taxable person that provides another taxable person with resources creating the latter's FE is not disappearing as such or, in other words, it is not becoming per se the FE of this another taxable person. ${ }^{67}$ Thus, at the location of the FE the latter and the third party whose resources created the FE further exist separately from the perspective of VAT.

In this context a question arises whether the Societas Europea and its local branches would be considered as head office - FE structure. According to the EC, Societas Europea is subject to VAT in various MS where its FEs are located. ${ }^{68}$ It should not however be concluded by default that branches of Societas Europea are always the FEs. Societas Europea is a special cross-border entity whose most common internal structure is a central office - branch structure. ${ }^{69}$ Societas Europea is usually established by businesses that already operate cross-border through branches or subsidiaries in other MS. ${ }^{70}$ If before the creation of the Societas Europea subsidiaries or branches were engaged in the individual business activities, they might further do so and bear the risks related to the activities even after the transformation into the Societas Europea. ${ }^{71}$ Thus, branches of the Societas Europea can only create FEs of the central office if all the standard conditions for the creation of the FE are met. The supplies of services between the central office and its branch should thus fall outside of the scope of VAT only where they are effected with the branch as a FE and not a branch as an independent taxable person engaged in taxable activities separate from the activities of its head office. ${ }^{72}$

\subsection{The possession of a suitable structure of human and technical resources}

\subsubsection{Human and/or technical resources}

For the FE to be created it is necessary that the core functions inherent in the supply are carried out at the location of the establishment and this can only be done when certain resources capable of doing so are present. As the CoJ indicated for the first time in its judgment in Berkholz, these are the human and technical resources. ${ }^{73}$ In 1985 when the judgment was issued provision of most of the services was hardly imaginable without the human resources. On the one hand, this likely was one of the reasons why the CoJ

the supplier and at the same time created the FE of the Cypriot-company, see Opinion of AG Kokott in Welmory, C-605/12, EU:C:2014:366, para. 51.

${ }^{67}$ Opinion of AG Kokott in Welmory, EU:C:2014:366, para 52.

${ }^{68}$ European Commission Memorandum of 8 October 2001 on frequently asked questions about the SE No MEMO/01/314, <http://europa.eu/rapid/press-release_MEMO-01-314_en.htm?locale=en>, accessed on 13 May 2014.

${ }^{69}$ Noëlle Lenoir, 'The Societas Europea (SE) in Europe. A promising start and an option with good prospects' [2008] March, Volume 5, Issue 1 Utrecht Law Review, 18.

${ }^{70}$ Council Regulation (EC) No 2157/2001 of 8 October 2001 on the Statute of European Company (SE) [2001] OJ L 294, Article 2.

${ }^{71}$ As it was already mentioned, according to the CoJ's judgment in FCE case this is only possible where they bear economic risk related to the activities they are engaged in, see Judgment in FCE, EC:C:2006:196, para 35.

${ }^{72}$ Similar view with respect to branches as independent taxable persons and taxation of supplies between the head office and the branch is shared by Ad van Doesum, Herman van Kesteren and Gert-Jan van Norden, 'The Internal Market and VAT: intra-group transactions of branches, subsidiaries and VAT Groups' [2007] 2007-1 EC Tax Review, 35.

${ }^{73}$ Judgment in Berkholz, EC:C:1985:299, para. 18. 
decided in Berkholz that no FE existed on board of a ship as only the technical means were permanently present there; meanwhile human beings were present on the boats for maintenance and repair of the machines only occasionally.

On the other hand, it cannot be ignored that this conclusion was influenced by the fact that the CoJ did not see there being a rational result if the place of taxation is shifted to the location of the FE (if it existed) as the establishment would have been fixed-floating, i.e. existing in the territory of several countries during each voyage. This is confirmed by Faaborg case where both human and technical resources were permanently present on a ferryboat where the restaurant services were provided. In the judgment the CoJ stressed that no FE is created especially because the rational result can be reached when taxing services at the place of the principal business establishment of the supplier. ${ }^{74}$

Although it might be that in the said cases the conclusion of the CoJ was influenced by the aim to find the rational result ${ }^{75}$, the $\mathrm{CoJ}$ continued to repeat the same requirement of the joined resources in the later cases although as early as in the late 1990s scholars argued that if the CoJ or the EU legislator does not change the requirement of compulsory existence of the human resources, the tax system will 'slowly commit suicide $^{76}$ as websites and serves already enable provision of services without any intervention of human beings. ${ }^{77}$

In $R A L$ services analogous to the ones in Berkholz, except that provided some twenty years later and not on a ferryboat but in the amusement arcades in the UK, were under the examination. AG Maduro suggested that functions that are inherent in the supply of the gaming service (i.e. the conclusion of agreement and its performance by enabling the gaming but not including the payout of the winning, if any, and other ancillary activities) were performed solely by the machines installed in the UK which were considered by AG as capable of constituting resources necessary for the creation of the FE. ${ }^{78}$ In other words, AG considered that no human resources were needed for the actions that are the core in the supply to be performed. It is a pity that the CoJ did not reflect on the creation of the FE in its judgment. ${ }^{79}$ However, it is evident that the core

\footnotetext{
${ }^{74}$ Judgment in Faaborg, C-231/94, EC:C:1996:184, para. 18. The CoJ, however, avoided relying solely on the principle of primary point of reference (although the logic of the primary point of reference principle is that it has to be firstly determined whether the FE exists and only then whether a more rational result is reached by referring to the primary or to the secondary establishment).

${ }^{75}$ It is concluded by Madeleine Merkx that Berkholz and Faaborg cases do not represent the CoJ's actual opinion on the requirements for a suitable structure in terms of human and technical resources, see to that effect 'Establishments in European VAT' (n 19) 74.

${ }^{76}$ Ben J.M. Terra, 'BTW en het elektronische handelsverkeer' [1998] 6301 Weekblad fiscaal recht, para. 1049, referred to in Pasquale Pistone, 'Fixed Establishment and Permanent Establishment' (n 23) p. 104, n. 26.

77 This was taken into account by the EU legislator as the place of supply rule for electronic services supplied by non-EU suppliers to non-taxable EU customers was changed and MOSS was introduced as of 1 July 2003. These special provisions apply to services that are in most cases related to automated supplies of services via internet or other electronic networks where human intervention is non-existent or insignificant and ensures taxation at the place of the establishment of the customer that eliminates the relevance of the FE of the supplier. Analogous change for the supplies of electronic services supplied by the EU suppliers and supplies of telecommunications and broadcasting services will come into force as of 1 January 2015. However, as illustrated by Berkholz and RAL cases, the use of solely the technical means in the supplies goes far beyond the supplies of electronic services.

${ }^{78}$ Opinion of AG Maduro in RAL, EU:C:2005:65, para. 55.

79 The CoJ solved the case by applying not the general but the special place of supply rule for entertainment services where existence of the FE is irrelevant as the service is taxed where it is actually performed.
} 
functions inherent in the supply might be performed in certain situations by solely human or solely technical resources and thus can be sufficient to create the FE. ${ }^{80}$

Furthermore, the EU VAT system already contains rules relating to the FE that can be created solely by the technical means. That is the FE of the supplier of electronic services who can enjoy the MOSS only when he is not established in the EU and does not have the FE therein. Electronic services falling under the scheme are downloading of dematerialised goods (movies, songs, electronic articles, books etc.) or specific digital services (hosting of websites, storage of data in the clouds etc). These services are provided in an automated manner (via Internet or other electronic networks) and no or very limited human intervention is needed. ${ }^{81}$

It is, however, unclear which technical means should qualify as the sufficient technical resources. Neither the EU legislation nor the ECJ and the VAT Committee provide for an explanation. Currently in direct taxation the PE can only be created by the computer equipment (e.g. a server) but not data and software (e.g. a website) as the OECD Commentary requires tangible property to be present. ${ }^{82}$ However, in 2003 in the discussion draft of the Technical Advisory Group (the Group) on Monitoring the Application of Existing Treaty Norms for Taxing Business Profits in the OECD ${ }^{83}$, as well as in 2014 in the OECD's Public Discussion Draft on BEPS Action $1^{84}$ it was suggested to introduce a new nexus for the creation of the PE in the situations where business is conducted wholly digitally. The Group suggest introduction of one of the three alternative virtual PE thresholds: (i) a virtual fixed place of business $\mathrm{PE}^{85}$, (ii) a virtual agency $\mathrm{PE}^{86}$, or (iii) an on-site business presence $\mathrm{PE}^{87}$. Spain, one of the OECD members, in 2013 already went to the similar direction as its Central Tax Court decided on existence of the virtual PE of the Irish company Dell Products Limited in Spain. ${ }^{88}$ The company was treated as having the PE as it made sales into Spain through the website focused on a Spanish market, although the server on which the website was hosted was located outside of Spain. ${ }^{89}$

\footnotetext{
${ }^{80}$ Although it is true that human resources will be needed for the vast majority of the supplies for certain ancillary actions to be performed, e.g. maintenance of technical resources. The same view is shared by Marcin Gorazda and David Elvira Benito, 'Destination Principle in Intra-Community Services and the "Fixed Establishment" in the VAT. A Comparative Study of Polish and Spanish Law' (n 26) 125.

${ }^{81}$ Human resources are mostly used for set-up and maintenance of equipment used for automated supplies of services, except remote systems administration and distance maintenance of programs for which a higher demand of human beings' intervention is likely, see to that effect Annex I to the Implementing Regulation.

82 OECD Commentary on Paragraph 1 of Article 5 of the OECD Convention.

${ }^{83}<$ http://www.oecd.org/tax/transfer-pricing/20655083.pdf $>$, accessed 13 May 2014, p. 68.

$84<$ http://www.oecd.org/ctp/tax-challenges-digital-economy-discussion-draft-march-2014.pdf $>$, accessed 7 April 2014.

${ }^{85}$ Where a website hosted on a server of another enterprise could create a PE, see the Public Discussion Draft on BEPS Action 1, p. 66.

${ }^{86}$ Where a website through which the contracts binding on the foreign enterprise are habitually completed might be treated as a dependent agent permanent establishment of that enterprise regardless of the location of the server on which that web site is hosted, see the Public Discussion Draft on BEPS Action 1, p. 66.

${ }^{87}$ Where economic presence of an enterprise within a jurisdiction would attract source taxation without the need for a fixed place of business to exist in situations when on-site services or other business interface are provided at the customer's location, see the Public Discussion Draft on BEPS Action 1, p. 66.

${ }^{88}$ Currently the case is under the appeal procedure.

${ }^{89}<$ http://www.bna.com/spanish-court-imposes-n17179871765/> accessed 13 April 2014.
} 
The new nexus suggested in the Public Discussion Draft on BEPS Action 1 would exist where there is a significant digital presence in the economy of another country, e.g. when a significant number of contracts are remotely signed between the enterprise and the customers resident in the other jurisdictions, where digital services are widely used or consumed in another jurisdiction, where substantial payments are made from the clients resident in the other jurisdictions for the digital services etc.

In the field of VAT neither the Implementing Regulation nor the CoJ's case law raise a requirement for the technical resources to necessarily be tangible, meaning that in the wider sense a website could create the FE. On the other hand, it is often rather difficult to identify the location of the website, especially in situations where its owner hosts the website not on its own server but on a server of the independent service provider. In the latter situation the website may be hosted on several servers located in different places. Therefore, considering that the FE may be created by a website might encumber the functioning of the VAT system.

As to the even wider concept of the substantial digital presence discussed by OECD in the Public Discussion Draft on BEPS Action 1, if businesses are treated as having FEs in each and every country in which they have customers acquiring and using their services, operation of the VAT system would be hindered as majority of businesses would have many FEs worldwide. It is however not the task of the FE to shift the taxation to the location of the customer if it is believed that the consumption takes place there. This must be done through the place of supply rules in general (see to that effect Section 2.1).

In the EU VAT the place of supply of B2B services was already shifted to the location of the customer as it is believed that they use the majority of these services there for the purposes of the subsequent supplies of goods and/or services. In B2C supplies such a shifting for administrative reasons was limited to the electronic services. Thus, the EU is already addressing the challenges relating to the electronic commerce. Expansion of the FE concept to the same direction as it is suggested to be done in direct taxation would lead to the current place of supply rules losing their efficiency as suppliers would have many FEs EU-wide and could not enjoy the benefits of the reverse charge and MOSS.

Respectively, the FE should only appear where technical resources in the narrow sense (i.e. the server or other technical means) are located in the jurisdiction other than where the primary business establishment is located if such a server enables functions forming the core of a particular supply to be performed without the direct use of the human resources.

\subsubsection{Possession}

Another important question is the possession of the human and technical resources. ${ }^{90}$ Although the term possession was firstly mentioned by the CoJ only in ARO Lease, it was important as of the first FE related cases. In Berkholz and Faaborg the CoJ mentioned 'having' and 'entailing' of resources. This was naturally accepted as a

\footnotetext{
90 Joep Swinkels refers to possession (of a framework in which agreements may be drawn up and management decision taken to enable the service to be supplied on an independent basis) as dependence of the FE on the head office; see Joep Swinkels, 'Fixed Establishments and VAT-Saving Schemes' (n 30) 417. This definition, however, brings confusion with the requirement brought by the CoJ in the $A R O$ Lease case for the FE to supply services on an independent basis and independence referred to by the CoJ in FCE case.
} 
condition for the supplier to own resources that are placed at its FE and used in the provision of the services.

$D F D S$ case proved it not to be the case. In $D F D S$ exclusively the resources of a separate taxable person (a subsidiary called DFDS-UK) were used performing the functions forming the core of the tour operator's DFDS-DK services (reselling of tour packages). DFDS-UK was reselling the packages in the name and on the account of DFDS-DK and, based on the contractual arrangements, did not bear any related financial risks. The fact that DFDS-UK was a separate taxable person was not an obstacle for the CoJ to rule that DFDS-DK had resources necessary to supply the services and thus sufficient for the FE to be created in the UK. The CoJ based this conclusion on two sets of facts: first, DFDS-UK was wholly owned by DFDS-UK, and, second, DFDS-DK imposed various contractual obligations on the subsidiary (as AG Maduro recalled in his opinion in $R A L$, contractual arrangements made the resources being under the direct dependence of DFDS-DK $\left.{ }^{91}\right){ }^{92}$ It was not however indicated in the decision whether these two requirements are cumulative or one of them is prerequisite, as well as whether the size of the shareholding is of any relevance. These issues were not under the direct examination in any of the later cases but are expected to be addressed by the CoJ in the currently pending Welmory case.

In 2009 Welmory Sp. Z o.o. (Welmory-PL) and Welmory Ltd. (Cypriot-Company) entered into a cooperation agreement. Under the agreement the Cypriot-Company had to operate, in the Polish language, a website for the internet auctions. Welmory-PL had to sell the goods on its own account on this website. Customers intending to buy the goods at the auctions had to acquire special bidding permissions from the Cypriot-Company. Respectively, under the scheme one taxable supply to the customer was made by Welmory-PL and the other by the Cypriot-company. The core aspect of the case is that under the cooperation agreement Welmory-PL provided the Cypriot-Company with the human and technical resources needed for the operation of the website. A dispute in the national case arose because of the taxation of these services with VAT, i.e. whether under Articles 44 and 196 of the VAT Directive the Cypriot-Company has to account VAT under the reverse charge in Cyprus or Welmory-PL has to account VAT in Poland since it supplied these services to the FE of the Cypriot-Company located in Poland. ${ }^{93}$

Although the question of the referring court mentions only Article 44 of the VAT Directive, it seems from the established practice of the Polish courts that the referring court considered the Cypriot-Company having an active FE in Poland that acquired the services from Welmory-PL for its own needs (carrying out taxable supplies to the Polish customers). This stems, firstly, from the fact that currently the Polish courts consider that services are taxable at the location of the FE only when they are used in the

\footnotetext{
${ }^{91}$ Opinion of AG Maduro in RAL, EC:C:2005:65, para. 50.

92 Under these contractual arrangements DFDS-UK had the following obligations: make available qualified sales and operational personnel, deal with passengers' complaints, make reservation of the trip and accommodation (by accessing the DFDS-DK's central computer), accept payments, provide the customer with the requisite documentation issued in the name of DFDS-DK, handle customer's claims. DFDS-UK was obliged under the agency agreement to coordinate its actions, especially from the financial point of view, with DFDS-DK, e.g. to obtain approval for conclusion of the major contracts with the customers, for appointment of public relations agents and management staff, to follow DFDS-DK's policy as regards advertising and marketing, handling of customers' complaints and etc., see Judgment in DFDS, EC:C:1997:77, para. 25.

${ }^{93}$ Opinion of AG Kokott in Welmory, EC:C:2014:366, paras 9-14.
} 
economic activities carried out by that $\mathrm{FE}^{94}$ and, secondly, from the arguments of the referring court that services acquired from Welmory-PL seem to have been consumed in Poland where the customers targeted by the Cypriot-Company were located. ${ }^{95}$ Despite that, AG Kokott in her opinion of 15 May 2014 alleged that the passive and active FE may exist separately and continued with the examination of existence of the passive FE of the Cypriot-Company ignoring the potential existence of the active FE. ${ }^{96}$

What is important in this Section of the thesis is that AG Kokott was of the opinion that for the creation of the passive FE, as Article 11 of the Implementing Regulation suggests, the same criteria on the possession of human and technical resources as for the creation of the active FE are applied. This, in the opinion of AG Kokott, enables the reference to the previous practice of the CoJ to be made even though it only relates to the active FE. ${ }^{97}$ However, AG Kokott did not in essence refer to the conditions on the possession of the resources raised by the CoJ in the previous case law, especially in $D F D S$. It is true that AG Kokott mentioned the judgment in $D F D S$, in particular that the $\mathrm{CoJ}$ concluded therein that the subsidiary was acting as a mere auxiliary organ of its parent because, firstly, it was wholly owned by it and, secondly, various contractual obligations were imposed on the subsidiary by the parent. However, in her further analysis AG ignored DFDS and did not at all analyse whether the ownership of the capital of the subsidiary is of relevance (the case was related to the supplies carried out in January-April of 2010; only in April 2010 the Cypriot-Company increased the holding of the capital of Welmory-PL from $60 \%$ to $100 \%$ ). AG merely stated that $D F D S$, even though the ECJ referred in the judgment into the general place of supply rule, was related to the application of the current Article 307 of the VAT Directive setting a special place of supply rule for the services of tour operators and thus that there are no rules of general nature in $D F D S .^{98}$

This argument of AG Kokott is questionable as it implies that AG is of the opinion that the FE referred to in the current Articles 45 and 307 of the VAT Directive are two different concepts. There is, however, no legal ground for such a conclusion to be made and exactly because of non-existence of the said difference the CoJ referred to the general place of supply rule in its judgment in DFDS.

Furthermore, AG Kokott contended that there is a confirmation of the conclusion on non-applicability of DFDS in the CoJ's judgment in Daimler and Widex case. ${ }^{99}$ This, however, does not seem to be the case. In the paragraphs of Daimler and Widex to which AG referred, the CoJ merely stated that situations in DFDS and Daimler and Widex are different because in the latter no output supplies were made meanwhile for the application of the Directive 2008/9/EC this is of the primary relevance. ${ }^{100}$ The CoJ did not say, however, that if the presence of the FE is analysed, no reference could be made to $D F D S$ as regards the criterion of possession of resources.

Irrespective of the previously mentioned, ignoring DFDS AG Kokott simply concluded in her opinion that for the creation of the FE it is sufficient for the taxable person to be

\footnotetext{
${ }^{94}$ Marcin Gorazda and David Elvira Benito, 'Destination Principle in Intra-Community Services and the "Fixed Establishment" in the VAT. A Comparative Study of Polish and Spanish Law' (n 26) 129.

95 Referral of the Naczelny Sąd Administracyjny, para 16.2, see also paras 11 and $12<$ http://orzeczenia.nsa.gov.pl/doc/1BB1CD362E> accessed 15 May 2014.

${ }^{96}$ This aspect is discussed in more details in Section 4.1.1 of the thesis.

${ }^{97}$ Opinion of AG Kokott in Welmory, EU:C:2014:366, paras 37-40.

${ }^{98}$ Opinion of AG Kokott in Welmory, EU:C:2014:366, para. 35.

${ }^{99}$ Opinion of AG Kokott in Welmory, EU:C:2014:366, para. 36.

${ }^{100}$ Judgment in Daimler and Widex, Joined Cases C-318 and C-319, EU:C:2012:666, paras 46-50.
} 
able to dispose of the resources for its own needs, meanwhile the ownership of these resources is irrelevant. ${ }^{101}$ It remains to be seen whether the CoJ will properly address in its judgment the issues previously raised in $D F D S$ and will unambiguously answer the question whether only the contractual obligations imposed on the third person or also the ownership of the capital and its size are relevant for the possession of resources to be present and thus for the FE to be created.

It is submitted here that in the context of the supply of services and the need to possess the resources that are essential for the supply the contractual arrangements related to the making of these resources available and not the ownership over the capital of the third party, irrespective of its size, should be prerequisite. It is very well possible for the subsidiary to be $100 \%$ owned by the parent and not to make any resources available for the supply of the parent's services. In the contrary, it is very well possible for a third party that is not owned by another taxable person to make available the resources needed for making its supplies.

It can be argued that the CoJ, although did not state that explicitly in its judgments, followed this opinion in the cases that followed DFDS. For example, in ARO Lease the self-employed intermediaries who were not owned or otherwise controlled by ARO Lease actually made the resources (in this case - human resources) available to ARO Lease. The CoJ decided that no FE was created not because of the lack of ownership over the resources but because based on the contractual arrangements the resources were only used for marketing (bringing the supplier and the customers into contact) and not in the performance of the core functions inherent in the supply of a leasing service (as discussed in Section 3.1).

The same opinion seems to be shared by AG Maduro. He stated in his opinion in $R A L$ that the contractual arrangements between Machines and CI enabled the latter to use the machines in performing the functions forming the core of the gaming service that it supplied and thus the FE should have been created. Meanwhile although the other group companies also made certain resources available to CI, they were not used to perform the core functions inherent in the supply of the gaming service and thus were considered as irrelevant for the purposes of creation of the FE. Ownership over the capital of the group companies was not considered relevant by AG Maduro and was not mentioned in the opinion.

\subsection{Permanence}

Already in Berkholz the CoJ stated that the FE is created only when it entails a permanent presence of human and technical resources used in the supply of services. ${ }^{102}$ This condition was repeated by the $\mathrm{CoJ}$ in all the later judgments. In the beginning of 2014 the Commission of the EU shortly mentioned in its opinion to the VAT Committee that 'since the intensity of an economic activity can vary over time, it is crucially important that the existence of "suitable structure in terms of human and technical resources" is examined over a period of time long enough to characterize the sufficient permanence [...]'. ${ }^{103}$ This is so far the only guidance as neither the CoJ nor the VAT Committee has provided any explanations on the permanence criterion. It remains to be seen what the VAT Committee includes in its guideline.

\footnotetext{
${ }^{101}$ Opinion of AG Kokott in Welmory, EU:C:2014:366, paras 48 and 56.

102 Judgment in Berkholz, EU:C:1985:299, para. 19.

${ }^{103}$ VAT Committee Working Paper No 791 Concerning the Application of EU VAT Provisions.
} 
Although the lack of clarity exists, the practical relevance of his criteria is significant as without a certain threshold the supplier having just once performed the functions forming the core of one supply made to the foreign customer using the resources present in a foreign jurisdiction would be considered as having the FE. This would pervert the concept itself as well as the rules on the place of supply as place of taxation in B2C supplies would factually shift to the customer's jurisdiction. ${ }^{104}$ Accordingly, it is important for a clearer guidance to be given either in the legislation or by the CoJ.

Some authors suggest setting an absolute period as a threshold for the FE to be created as it is done in direct taxation. It is proposed that the FE should only be created if services are actually supplied through that FE during that period. The number of the services provided through the FE, as well as their nature and scale is named to be unimportant. ${ }^{105}$ However, if the rules of direct taxation are followed with this respect, the exceptions set in the OECD Convention should also be taken into account. Firstly, certain types of economic activities have specifics due to which output supplies can only be effected for a short period of time, although very actively. Secondly, rules related to recurrent taxable supplies should be set as otherwise taxpayers would be enabled to divide their economic activities carried out through the FE in periods each of which taken separately would not create the FE. Thirdly, the FE should not be created where supplies effected through the FE are only occasional or sporadic. ${ }^{106}$ As to the last point, CoJ's practice on the definition of 'economic activities' should be taken into account as the $\mathrm{CoJ}$ has concluded that occasional activities in general cannot amount to economic activities. ${ }^{107}$

Therefore, a mixture of different criteria should be used, similarly as it is done in the direct taxation. ${ }^{108}$ It is true that the mixture of criteria does not provide the taxpayers with a desired legal certainty and does not ease either the tax compliance or the tax administration. However, solely setting an absolute period without any alternatives and exceptions will often not reflect the actual economic situation and will create a field for manipulations.

The starting and ending points of the active FE need to be set as well. As to the starting point, in the direct taxation intentions of the businesses are taken into account. If it is planned that activities will not exceed the set threshold but later they do, the PE has to be registered and tax on income attributed to the PE have to be paid retroactively. In corporate taxation taxable period is normally a calendar month meanwhile the set threshold is often six or nine months, meaning that businesses not always need to adjust already submitted reports. As VAT has to be accounted on transaction-by-transaction basis at the time the supply is made, it would be rather burdensome for the businesses to adjust VAT on all the pervious supplies after the change of the business plans. In addition, differently from the direct taxation, customers would also have to be involved in the adjustment procedures. Therefore, considering the peculiarities related to VAT accounting the starting point of the FE should be the first transaction effected after the

\footnotetext{
${ }^{104}$ Although, as concluded in Section 3.2.1, it is not the role of the FE to shift the place of taxation to the location of the customer.

${ }^{105}$ Madeleine Merkx, Establishments in European VAT (n 19) p. 77.

106 For example, if the absolute term set is six months and during this period only two supplies are effected through the establishment, one on the very first and the second on the very last day of that period (and no transactions are carried out later). See to that effect Jean Schaffner, 'The Territorial Link as a Condition to Create a Permanent Establishment' [2013] Volume 41, Issue 12 Intertax, 641.

${ }^{107}$ Except occasional activities that are treated as economic activities pursuant to Article 12 of the VAT Directive, see Judgment in Renate Enkler, C-230/94, EU:C:1996:352, paras 20 and 29.

${ }^{108}$ See to that effect OECD Commentary to Article 1 of the OECD Convention.
} 
set time threshold is exceeded. The ending point should be the last transaction effected by the FE.

\section{Creation of the passive $F E$ and attribution of acquisitions thereto}

\subsection{Independent existence of the passive $\mathbf{F E}$}

The Implementing Regulation contains two separate definitions of the FE: active and passive one. The passive FE is defined as an establishment other than the primary business establishment 'characterized by a sufficient degree of permanence and a suitable structure in terms of human and technical resources enabling it to receive and use the services supplied to it for its own needs'. ${ }^{109}$

Some authors are of the opinion that the existence of the two separate definitions in the Implementing Regulation is sufficient to conclude that an establishment may not qualify as an active FE but it may qualify as a passive one. ${ }^{110}$ Others contend that if the FE acquires the service, the place of taxation should be at the location of the FE as the principle of taxation at the place of the actual consumption is better reflected then. ${ }^{111}$ There are, however, opinions that the passive FE cannot exist independently from the active FE for the purposes of Article 44 of the VAT Directive. ${ }^{112}$

Practice of most of the MS, e.g. the UK, France, Belgium, Lithuania, as well as opinion of the Commission of the EU is to treat the passive FE as capable of existing independently. ${ }^{113}$ This is of great relevance for the companies having representative offices or buying agents in the foreign jurisdictions. Analysis provided below raises doubts whether the independent existence of the passive FE is in line with the EU VAT system.

\subsubsection{Ability to use the services for its own needs}

Pursuant to Paragraph 2 of Article 21 of the Implementing Regulation, the passive FE can only exist when it is capable of using the acquired services for its own needs. It is, however, not explained when the service is used for the needs of the FE. In the wide sense, this would be any use for the purposes of the activities the passive FE is engaged in (e.g. representative office responsible for marketing of the supplier's business in a particular jurisdiction acquires services of marketing consultants). In the narrow sense, however, the use of the acquired services needs to be related to carrying out of economic activities at the location of the FE.

\footnotetext{
${ }^{109}$ Article 11(1) of the Implementing Regulation.

${ }^{110}$ Ine Lejeune, Ellen Cortvriend and David Accorsi, 'Implementing Measures Relating to EU Place-ofSupply Rules: Are Business Issues Solved and Is Certainty Provided?' [2011] May/June International VAT Monitor, 147.

${ }^{111}$ Ben J.M. Terra, The VAT Package and anti-tax fraud measures (n 5) 65. In addition, as Madeleine Merkx explains, the presence of the passive FE in a MS means that it will use the government facilities provided by that MS and this country will be the country of the actual consumption and spending for this passive FE, see Establishments in European VAT (n 19) 94. However, as it was concluded in Section 2.2, the FE is used as a proxy in the place of supply rules and is not necessarily the place of the actual consumption.

${ }_{112}$ Madeleine Merkx, Establishments in European VAT (n 19) 96.

${ }^{113}$ Madeleine Merkx, Establishments in European VAT (n 19) 93; Lietuvos Respublikos Pridetinès vertès mokesčio istatymo 13 straipsnio apibendrintas komentaras (Commentary to the Law on VAT of the Republic of Lithuania) < http://mic.vmi.lt/documentpublicone.do?id=1000130133>, last accessed on 13 May 2014); VAT Committee Working paper No 791 Concerning the Application of EU VAT Provisions (n 103).
} 
As it was already mentioned, some authors contend that the principle of taxation at the place of the actual consumption requires the independent existence of the passive FE. ${ }^{114}$ What is however important is that for VAT purposes consumption is expenditure, which can be either consumptive or productive. ${ }^{115}$ In B2B supplies only the productive expenditure, characterised as expenditure for the purposes of making subsequent sales, is relevant. ${ }^{116}$ It follows that for businesses the place of consumption for VAT purposes is the place where businesses will use the acquired services for making the subsequent supplies of goods and services. Therefore, the acquired services should be attributed to the establishment that uses the services for carrying out of the taxable output supplies. The establishment that is only engaged in the acquisitions should be irrelevant with this respect.

Furthermore, as the passive FE will not use the acquired services in its own economic activities, it will re-route the services to the establishment that will do so. As the threshold for creation of merely the passive FE is much lower, legitimate independent existence thereof creates much greater possibilities for channelling of acquisitions through the FEs located in the foreign jurisdictions providing the more favourable tax treatments of the supplies. ${ }^{117}$ This should not be encouraged by the legislator. ${ }^{118}$

In the contrary, AG Kokott contended in her opinion in Welmory case that the independent existence of the passive FE is possible. However, arguments provided in the opinion can be criticized. First of all, AG submitted that the requirement for the FE to be engaged in the economic activities would collide with Article 43(2) of the VAT Directive under which non-taxable legal person identified for VAT purposes is regarded as a taxable person for the purposes of place of supply of services. ${ }^{119}$ However, acquisitions of the non-taxable legal person identified for VAT purposes are subjected to Articles 44 and 196 of the VAT Directive for administrative reasons as this person is already identified for VAT and thus with no additional disproportionate administrative burden can account VAT in the MS where it is established. The fact that it does not engage in economic activities merely means that it will never have a FE in another MS and thus the services will always be taxable at the location of its main establishment. Subjecting supplies of a particular person to the general place of supply rule that makes a secondary reference to the FE does not necessarily mean that this person should be capable of creating the FE. Furthermore, AG also mentioned that the principle of primary point of reference must be applied and where there are any doubts on the existence of the FE, a negative conclusion should be made and thus services taxed at the location of the principal business establishment. ${ }^{120}$ Moreover, AG admitted that the Cypriot-Company also has an active FE as it has to supply services under the cooperation agreement with Welmory-PL and, in addition, said that it is likely that any structure of resources creating a passive FE would be able to engage in taxable output supplies. ${ }^{121}$ It remains to be seen whether the CoJ in its judgment will elaborate on this aspect.

\footnotetext{
114 Although there are opinions that this principle should not apply to B2B supplies, it is currently so applied, see to that effect Madeleine Merkx, Establishments in European VAT (n 19) 96.

${ }^{115}$ Ben J.M. Terra and Julie Kajus, Introduction to European VAT (n 19) Section 7.2.2.

$116<$ http://georgereisman.com/blogWP/?tag=productive-expenditure $>$, accessed 4 May 2014.

${ }^{117}$ Madleine Merkx, Establishments in European VAT (n 19) 93.

${ }^{118}$ See more on channelling of acquisitions in Section 4.2.2.

${ }^{119}$ Opinion of AG Kokott in Welmory, EU:C:2014:366, para. 43.

${ }^{120}$ Opinion of AG Kokott in Welmory, EU:C:2014:366, para. 45.

${ }^{121}$ Opinion of AG Kokott in Welmory, EU:C:2014:366, para. 43.
} 
Daimler case can be taken as an illustration of the ambiguous CoJ's position on the independent existence of the passive FE. Daimler-DE acquired services to be used in testing activities in Sweden and was prohibited of getting input VAT refunded on the basis of the Directive 2008/9/EC as it was considered having the active FE in Sweden. ${ }^{122}$ The CoJ did not agree with the Swedish tax authorities on the existence of the active FE and concluded that Daimler-DE is entitled to get the input VAT refunded under the Directive 2008/9/EC. Furthermore, the CoJ concluded that Daimler-SE is a taxable legal person on its own account and that the purchases at issue in the main proceedings were not made by it. ${ }^{123}$ In other words, the CoJ did not consider the possibility of treating the subsidiary as having created a passive FE of Daimler-DE and ascribing these acquisitions to this FE instead of the head office, although the acquired services were used at the testing installations (it remains unclear in these circumstances why the Swedish VAT was at all incurred ${ }^{124}$ ). By this conclusion the CoJ raised ambiguity on its opinion on the independent existence of the passive FE.

\subsubsection{VAT identification}

In the opinion of Commission of the EU, presence of the active and passive FE should be assessed separately and each operator has to ensure that such FEs are properly identified for VAT purposes (which would be necessary in order to enjoy the VAT deduction in the VAT return). ${ }^{125}$ However, the operators are not provided with the legal ground for registration of the passive FE.

Article 214(d) refers to persons acquiring services, however, only when under Article 196 the reverse charge applies and these persons are obliged to account VAT on the acquisition. However, in situations where reverse charge is not applicable (e.g. when the supplier is established at the location of the passive FE), the passive FE is not entitled to VAT register on the ground of this or any other Article. It is thus questionable how the suppliers and tax administrators should at all be aware of the existence of the passive FE which cannot be VAT identified. ${ }^{126}$

\subsubsection{Deductibility of input VAT}

Taxable persons engaged in economic activities are entitled to input VAT deduction which has to ensure the neutrality of VAT and shift the burden of the tax to the final consumer. The $\mathrm{CoJ}$ in its decision in Le Credit Lyonnais indicated that when a person has a principal business establishment in one jurisdiction and one or several secondary establishments (FE) in other jurisdictions, it is for each establishment to seek independent VAT deduction in the jurisdiction where it is located in respect of acquisitions made there. ${ }^{127}$ In addition, in situations where the direct link between the input VAT and the taxable output transaction cannot be established and pro-rata deduction has to be made, each establishment has to calculate its own pro-rata based on the acquisitions and supplies made in their jurisdiction and no worldwide pro-rata is

\footnotetext{
${ }^{122}$ It is not clear whether in such circumstances the Swedish tax authorities would have then agreed that Daimler-DE has a right to input VAT deduction instead of the refund.

${ }^{123}$ Judgment in Daimler and Widex, EU:C:2012:666, para. 20.

${ }^{124}$ Ben J.M. Terra and Julie Kajus, Introduction to European VAT (n 19) Section 11.4.2.1.

${ }^{125}$ VAT Committee Working paper No 791 Concerning the Application of EU VAT Provisions, 4.

${ }^{126}$ Registration with the public register of the establishment having a certain legal form ascribed under the national civil law might be one of the indicators of potential existence of the FE. This will however be so only if the establishment has a form of a branch, a representative office or a subsidiary. Other types of FE will remain unidentified.

${ }^{127}$ Judgment in Le Credit Lyonnais, C-565/12, EU:C:2014:190, para. 33.
} 
applied. ${ }^{128}$ The principal business establishment may not take into account the turnover of its FEs established in the other jurisdictions and vice versa. ${ }^{129}$ Respectively, it is questionable whether the passive FE would be able to deduct the input VAT incurred on the acquisitions attributed to it.

Article 168 of the VAT Directive indicates that input VAT can be deducted from the payable output VAT in so far as the acquired services are used for the purposes of the taxed transactions of the taxable person. The passive FE is, however, not engaged in any economic activities - only the head office is. The $\mathrm{CoJ}$ has explained in Rompelman and Inzo cases that preparatory acts, such as acquisitions of assets, must themselves be treated as economic activities when the person has an intention to begin the economic activities giving rise to the taxable transactions. ${ }^{130}$ The activities of the passive FE, however, differ from the preparatory activities as there is no intention for the FE to engage in the taxable output transactions. Therefore, in the light of Le Credit Lyonnais case it can be concluded that the passive FE could not independently enjoy its right to input VAT deduction.

In such circumstances it is questionable whether the head office could get the VAT refunded under the Refund Directives. Both of them require the applicant not to be established in the country of refund (i.e. not to have the principal business establishment or the FE) and not to have carried out taxable output supplies the place of supply of which is the country of refund (except where reverse charge is applied). The latter condition would likely be met as the passive FE would not be engaged in the output supplies at all. As to the former condition, on the one hand the Refund Directives seem to refer solely to the active FE. On the other hand, taking into consideration the whole EU VAT system and the structure of the VAT accounting and deductibility rules, it is illogical to shift the place of taxation to the location of the passive FE and even to require the FE to account and pay the VAT under the reverse charge, and at the same time to require the head office to get the refund of VAT using the directives intended to be applied to persons not established in the MS of refund. ${ }^{131}$ After the main place of supply rule for B2B supplies was changed, the amount of requests for input VAT refund under the Refund Directives reduced significantly and it contributes to the more efficient implementation of the fiscal neutrality principle as naturally refund is a more time consuming procedure than the deduction of the input VAT in the VAT return. ${ }^{132}$ Existence of the passive FE would cancel this result.

To sum up, the condition inherent in Article 11(2) of the Implementing Regulation requiring the establishment to use the services 'for its own needs' should be understood as referring to the use of the acquired services in the economic activities carried out by

\footnotetext{
128 PricewaterhouseCoopers on Le Credit Lyonnais $<$ http://www.outlaw.com/articles/2013/september/credit-lyonnais-decision-shows-deficiencies-in-eus-vat-treatment-ofinternational-branches-says-expert/> accessed 13 May 2014.

${ }^{129}$ Judgment in Le Credit Lyonnais, EU:C:2014:190, paras 40 and 49.

130 Judgment in Rompelman, C-268/83, EU:C:1985:74, para. 24; Judgment in Inzo, C-110/94, EU:C:1996:67, para. 18.

${ }^{131}$ Such a system exists in Lithuania where the passive FE needs to report the due VAT in a special report on VAT obligations of non-VAT-identified persons and pay the VAT to the revenue. The non-resident head office has to subsequently claim the refund of the VAT under one of the Refund Directives, see Lietuvos Respublikos Pridètinès vertès mokesčio įstatymo 13 straipsnio apibendrintas komentaras (Commentary to Article 13 of the Law on VAT of the Republic of Lithuania) $<$ http://mic.vmi.lt/documentpublicone.do?id=1000130133>, accessed 13 May 2014).

132 Casper Bjerregaard Eskildsen, 'Pro Rata Deduction by Entities Established in Several VAT Jurisdictions' [2012] January/February International VAT Monitor, 28.
} 
the FE. ${ }^{133}$ The term 'use' would then be understood in the same manner as it is understood for the purposes of Article 168 of the VAT Directive and would ensure the consistency in the EU VAT system. Respectively, the Implementing Regulation should be considered not as providing two definitions of two separate concepts capable of existing independently but instead as simply separately defining two different functions, passive and active, one FE can perform without acknowledging that the buying FE can exist independently.

\subsection{Attribution of acquisitions to the customer's FE and mitigation of tax manipulations}

\subsubsection{The attribution rules}

Another rather complicated issue related to the passive role of the FE is attribution of acquisitions thereto. This is of particular importance not only for the place of supply and the application of the reverse charge but also for the input VAT deductibility as described in the further Sections.

Article 22 of the Implementing Regulation provides a rather vague guidance on attribution of a service to one of the establishments of the customer. The supplier has to determine which of the customer's establishments acquires the service based on, firstly, the nature and use of the service, and, secondly, in whose name the contract and/or the order form is signed, whose VAT identification number is communicated to the supplier and which establishment is paying for the service.

Although the supplier is able to determine the nature of the service, it is doubtful whether knowing the nature will help much when determining which of the establishments of the customer will actually benefit from the service. ${ }^{134}$ Thus, the supplier undertakes a risk for the incorrect attribution based on his own judgment or instead applies the second rule and relies on the data provided by the customer. ${ }^{135}$ Where this data is incoherent or insufficient or in the case of global contracts ${ }^{136}$, the supplier refers to the last rule stipulated in Paragraph 3 of Article 22(1) of the Implementing Regulation which allows attribution of the service to the principal business establishment. ${ }^{137}$

\footnotetext{
133 The same approach is upheld in Poland where national courts consider that acquisition and consumption of services referred to in Article 44 of the VAT Directive must be directly related to the economic activities carried by that establishment. In the absence of such economic activities, being provided with the services consumed by that establishment cannot determine its fixed character or, in other words, cannot create the FE. See Marcin Gorazda and David Elvira Benito, 'Destination Principle in Intra-Community Services and the "Fixed Establishment" in the VAT. A Comparative Study of Polish and Spanish Law' (n 26) 129.

${ }^{134}$ Madeleine Merkx, 'Fixed Establishment and VAT Liabilities under EU VAT - Between Delusion and Reality' (n 61) 23.

${ }^{135}$ The risk for the supplier is laying in the fact that the tax administrator of his jurisdiction may disagree with the attribution made. In a situation where, pursuant to the tax administrator, the establishment actually using the service is located in the same jurisdiction as the supplier, the latter might be assessed with additional output VAT that he did not invoice to the customer. In situations where the supplier attributed the supply to a wrong but still a foreign establishment, only administrative issues related to non-corresponding reports on intra-EU supplies are likely to occur.

${ }^{136}$ Services acquired under the global contracts are used in unidentifiable and unquantifiable manner.

137 Application of this rule, however, does not prevent the supplier from difficulties as he needs to determine where the head office is located. Based on the CoJ's judgment in Planzer (paras 60-61) and later adopted Article 10 of the Implementing Regulation, location of the head office is where the functions of the central administration are carried out. The latter place should be determined based on
} 


\subsubsection{The risk of tax manipulations}

As the attribution made by the supplier to a large extent depends on the information provided by the customer, the latter can manipulate the data he provides to the supplier and so easily channel the acquisitions of services through the FEs located in the jurisdictions providing a more favourable VAT treatment of the supplies.

The channelling is attractive due to the fact that the CoJ in its judgment in FCE case ruled that supplies between the head office and the FE located in different MS (or vice versa) are not subject to VAT as they are made within a single legal entity and single taxable person. ${ }^{138}$ This means that customers, especially those engaged in exempt supplies, might channel acquisitions through the FE located in the MS which, for example, exempt particular supplies from VAT, and subsequently re-route the services to the other establishments free of VAT. Presuming that the rule of FCE is applicable when one of the establishments is located outside of the EU, the customer might channel the acquisitions through the FEs located in jurisdictions where there is no VAT at all and subsequently re-route the service to the establishments located in the EU free of VAT.

In addition, the approach of the EU to treat intra-entity supplies as falling outside of the scope of VAT is rather unique if compared to the other countries having in general rather similar VAT systems. Therefore, channelling of the acquisitions through the FE located in the jurisdictions in which intra-entity supplies are recognised for VAT purposes entitles the acquiring FE to the full input VAT deduction. The subsequent rerouting of that service to another establishment located in the EU is in the meantime not subject to VAT. Thus, the service is acquired free of VAT. ${ }^{139}$

Furthermore, even where in the jurisdiction where the FE through which the acquisition is channelled is located does not exempt the supply from VAT, VAT saving opportunities exist. The $\mathrm{CoJ}$ ruled in Le Credit Lyonnais that each establishment needs to seek for input VAT deduction in its jurisdiction independently and calculate its own pro-rata without taking into account the turnover of the other establishments. ${ }^{140}$ Therefore, the customers might channel the acquisitions through the FEs having the higher pro-rata ratios for input VAT deduction. ${ }^{141}$

where the essential decisions concerning the management are taken, where the registered office is located and where the management meets, the first one having precedence.

${ }^{138}$ Judgment in FCE, C-210/04, EU:C:2006:196, paras 37 and 41.

${ }^{139}$ E.g., FE located in Switzerland, through which the acquisition is channelled, would be entitled to input VAT deduction as its subsequent reselling of the service would be inside of the scope of EU VAT from the Swiss VAT law perspective. Establishment located in the EU to which the service is re-routed would not be obliged to account VAT under the reverse charge as from the EU VAT perspective this acquisition would be outside of the scope of VAT. See more on the Swiss VAT aspects related to head office - FE relationship in Pierre-Marie Glauser, 'Head Office/Branch Relationship from the Perspective of Swiss VAT’ [2010] January/February International VAT Monitor, 31-35.

140 Judgment in Le Credit Lyonnais, EU:C:2014:190, paras 33 and 40.

${ }^{141}$ Pursuant to Article 168 of the VAT Directive and CoJ's case law (e.g. Judgment in Midland Bank, C98/98, EU:C:2000:300; Judgment in PPG Holding, C-26/12; EU:C:2013:526; Judgment in AES, C124/12, EU:C:2013:488) the first rule for input VAT deduction is direct attribution of the acquired service to the taxable output supply. However, one can consider that in the case of channelling such a link would not exist (as this establishment could not establish a direct link with any of its output supplies) and thus the costs of the FE through which the acquisition is channelled could only be treated as overheads (i.e. costs related to the business in general). Respectively, input VAT incurred on such acquisitions would only be deductible based on the pro-rata of the FE. 
Moreover, even non-exempt businesses, depending on the place of supply of a particular service, might gain benefits from the channelling of the acquisitions through the establishments located in the other jurisdictions than where the supplier is established from the perspective of cash flows as that entitles to application of the reverse charge mechanism. $^{142}$

Lastly, a contrary result may appear due to the application of the CoJ's judgment in Le Credit Lyonnais, especially in the case of global contracts. Head office to which the supply needs to be attributed pursuant to Paragraph 3 of Article 22(1) of the Implementing Regulation might not be entitled to get the refund of a rational amount of VAT as it cannot take into account the turnover of the FE who will partially use the service. If, for example, the pro-rata ratio of the head office is rather low, only a small amount of VAT will be deducted even though the majority of the services acquired under the global contract will be used by the fully taxable foreign FE.

\subsubsection{Mitigation remedies}

Theoretically channelling should not be possible in many of the situations described in the previous Section because of Article 22(2) of the Implementing Regulation under which irrespective of the attribution made by the supplier the customer needs to account VAT under the reverse charge in the MS where the establishment actually benefiting from the service is located. However, the MS in which the actual user of the service is established is not always aware that the supply/acquisition should have been subject to VAT therein ${ }^{143}$ and thus channelling opportunities are not restricted sufficiently. ${ }^{144}$

It is, therefore, suggested to minimise the attribution rules requiring determination of the place of the actual use of the service and use other measures for elimination of the negative effects related to the untaxed internal supplies and the establishments' right to the independent input VAT deduction. Suggested measures are the wider application of the internal supply rule and the cross-border VAT Grouping. ${ }^{145}$ It must be stressed that these measures are of huge relevance if it is considered that the passive FE can exists independently as it can be used in channelling acquisitions in a much broader manner then the FE that performs both active and passive functions. ${ }^{146}$

\footnotetext{
${ }^{142}$ E.g., instead of acquiring certain service through the FE located in the same jurisdiction as the supplier (which would require pre-financing of VAT), the customer might channel the acquisition through the FE located in another MS (which would entitle to the application of the reverse-charge and deduction of input VAT in the same VAT return).

${ }^{143}$ Joep Swinkels, 'Fixed Establishments and VAT saving schemes' (n 30) 241-242.

144 According to Madeleine Merkx, tax administrators should be able to track down the missing VAT through direct taxation as for direct taxes each establishment is treated as a separate taxpayer and thus costs are required to be recharged to the establishment that actually enjoys a particular service, see Establishments in European VAT (n 19) 129-130.

${ }^{145}$ Other measures such as the use of the abuse of law doctrine or elimination of exemptions will not be addressed in this thesis. See to that effect Madeleine Merkx, Establishments in EU VAT (n 19) 128-133; Christian Amand, 'VAT Grouping, FCE Bank and Force of Attraction' [2007] July/August International VAT Monitor, 247; Joep Swinkels, 'Fixed Establishments and VAT saving schemes' (n 30) 421. In the latter source the author questions whether the MS, which has not transposed Article 27 of the VAT Directive to its national law, is entitled to rely on the abuse of law doctrine.

${ }^{146}$ It must, however, be stressed that taxpayers are not required to choose business models resulting in the highest possible tax burden and, therefore, not all tax advantages gained by businesses is a result of abusive practices, see Judgment in Halifax, C-255/02, EU:C:2006:121; Judgment in Part Service, C425/06 EU:C:2008:108; Judgment in RBS Deutschland, C-277/09, EU:C:2010:810. Respectively, not all the situations should be subject to the application of anti-abuse rules, see to that effect Andrea Parolini, Carlos Bechara, Mariken van Hilten, Des Kruger, Rebecca Millar and Greg Sinfield, 'VAT and Group Companies' [2011] June Bulletin for International Taxation, 355-356.
} 


\subsubsection{Internal supplies}

Currently Article 27 of the VAT Directive provides a possibility for the MS, after consulting the VAT Committee, to treat as a supply of a service for consideration the supply by a taxable person of a service for the purposes of his business (i.e. self-supply), where the VAT on such a service, where it supplied by another taxable person, would not be wholly deductible. The result of this rule is that the taxable person must account for VAT on the acquisition of a service and may be entitled to deduct it based on the standard rules. This rule is used by some of the MS to ensure the equal treatment of exempt businesses who can and cannot in-source certain services for tax saving purposes. $^{147}$

If made mandatory, this rule could be used to mitigate tax saving opportunities in situations where the acquisitions of certain services are artificially channelled through the foreign establishments. ${ }^{148}$ It would become irrelevant to which establishment the supplier attributes the service and which establishment accounts for VAT under the reverse charge, if applicable. The FE which is indicated by the customer as the acquiring one (through which the acquisition is channelled) would be entitled to deduct the VAT accounted on the acquisition in full as the establishment which will actually use the service would have to account VAT on the internal supply which would be non/partially deductible if this FE has no/limited right to the input VAT deduction. ${ }^{149}$ This would lead to the right to recover input VAT being in line with the economic reality and it would become irrelevant through which establishment the acquisition is channelled. ${ }^{150}$

It must be mentioned that internal supply rule could serve as a great tool not only in artificial situations where acquisitions are channelled through particular establishments mainly for tax saving purposes but also in case of global contracts covering one or more services used in an unidentifiable and non-quantifiable manner which normally are concluded to reach economies of scale. Pursuant to Paragraph 3 of Article 22(1) of the Implementing Regulation these supplies have to be attributed to the head office. As normally such costs would have to be recharged for TP purposes to the FEs getting the benefit from the acquired service, from VAT perspective this recharging should be treated as an internal supply meaning that the establishment to which the part of the costs is recharged should account for VAT under Article 27 of the VAT Directive and

\footnotetext{
${ }^{147}$ Eight MS have consulted the VAT Committee in relation to transposition of Article 27 of the VAT Directive into their national laws; see

$<$ http://ec.europa.eu/taxation_customs/resources/documents/taxation/vat/key documents/vat committee/c onsultations_vat_committee_en.pdf $>$ accessed 6 May 2014. However, currently only Belgium applies internal supply rule and does that to a very limited extent - only for certain immovable property related services, see Joep Swinkels, 'Fixed Establishments and VAT-Saving Schemes' 27, n. 27.

${ }^{148}$ Ad van Doesum van Kesteren and Gert-Jan van Norden, 'The Internal Market and VAT: intra-group transactions of branches, subsidiaries and VAT groups' (n 67) 42.

149 Christian Amand, 'VAT Grouping, FCE Bank and Force of Attraction - The Internal Market is Leaking' (n 146) 247.

${ }^{150}$ The internal supply rule, however, would not always eliminate the cash-flow advantages reached by channelling of acquisitions of services. For example, if the supplier and the FE of the fully taxable business that will use the service are both established in one MS, in order for the reverse charge to be applied acquisition might be channelled through the head office or another FE located in another MS. In such a situation application of the internal supply rule would oblige the FE which will use the service to account for VAT in its MS but this VAT would be deductible in the same VAT return and thus the cashflow advantage would be saved, see Christian Amand, "Cross-Border Entities and EU VAT: A Contradictory Concept?’ [2010] January/February International VAT Monitor, 20.
} 
thus the supply would fall within the scope of VAT of the MS where the using FE is located as is required by the place of supply rule. ${ }^{151}$

TP principles in general can serve as a good tool in determining which of the establishments should account VAT on the internal supply. Alam Charlet and David Holmes suggested using TP principles when implementing the current attribution rules as transfer pricing analysis seeks to identify the establishment which benefits from the acquired services. However, the authors admit that channelling of acquisitions would be possible since TP strongly relies on the contractual terms. ${ }^{152}$ Therefore, TP principles could instead be used in determining which establishment should account VAT on the internal supply. It must be admitted that the principles governing corporate taxation and VAT systems, especially the fact that TP adjustments are normally made at the end of the taxable year, as well as valuation rules differ rather significantly. This would not allow making just one evaluation for the purposes of both corporate taxation and VAT. However, results of the TP analysis could be used for VAT purposes in determining the location of the establishment using the service and extent of such use. ${ }^{153}$

The result of accounting VAT on the internal supplies would be rather similar to the one of recharge method suggested by the OECD in the VAT/GST Guidelines. ${ }^{154}$ Under the recharge method the service would firstly be attributed to one of the establishments based on the agreement with the supplier or other documentation. Secondly, taxing rights would be allocated to the jurisdiction where the customer's establishment using the service is located. This recharge would be treated as a taxable supply and thus the recharging establishment would be entitled to input VAT deduction. ${ }^{155}$ However, adoption of this method would require changing of the law formed by the CoJ on intraentity supplies being outside of the scope of VAT. Therefore, the wider use of the internal supply concept would better fit into the current EU VAT system.

A problematic issue related to the internal supply rule is that under Article 77 of the VAT Directive taxable amount of the internal supply is the open market value. That is due to the fact that if the rule is applied to internally processed services, no other value exists. However, as channelling is mostly related to the externally acquired services, taxable amount of the internal supply could be equal or higher than the acquisition price. This would follow the rule of Article 76 of the VAT Directive applicable to analogous internal supplies of goods. ${ }^{156}$

\subsubsection{Cross-border VAT grouping}

\footnotetext{
${ }^{151}$ It should, however, be mentioned that for VAT purposes the actual recharging of costs is not relevant and thus the internal supply should take place even in situations where the establishment actually using the service does not in fact reimburse the costs of the establishment through which the acquisition is channelled.

${ }^{152}$ Alam Charlet and David Holmes, 'Determining the Place of Taxation of Transactions under VAT/GST: Can Transfer Principles Help?' [2010] November/December International VAT Monitor, 434436.

${ }^{153}$ Although under Article 63 VAT is due at the time of the supply, VAT could be accounted for internal supplies after the TP analysis is made, using the VAT adjustments mechanism, see to that effect Alam Charlet and David Holmes, 'Determining the Place of Taxation of Transactions under VAT/GST: Can Transfer Principles Help?' (n 152) 435.

154 VAT/GST Guidelines http://www.oecd.org/ctp/consumption/ConsolidatedGuidelines20130131.pdf accessed 13 May 2014, 31-32.

${ }^{155}$ Madeleine Merkx, 'Should EU VAT Apply the Recharge Method in the Place of Supply Rules for B2B Services?’ [2013] 2013-06 EC Tax Review, 283.

${ }^{156}$ Joep Swinkels, 'Scope of the Self-Supply Rule under EU VAT' [2008] May/June International VAT Monitor, 175.
} 
Application of cross-border VAT grouping would contribute to the elimination of the undesired financial benefits of exempt businesses gained from channelling acquisitions through the establishments having higher deductibility ratios or located in jurisdictions having more favourable taxation regimes of respective services. If such an establishment was joined to the VAT group, financial results of channelling would be minimised as: (i) input VAT incurred on the acquisition would be deductible based on the worldwide pro-rata of the group; and (ii) not the separate members but the group as such would acquire the services and thus under the general place of supply rule the group would have to account VAT on the acquisition in the MS where it is registered. Respectively, even when the services would be acquired from a jurisdiction where no VAT applies at all, EU VAT would be accounted at the location of the group. ${ }^{157}$

Cross-border VAT grouping might have various forms and each of them would give different benefits and inhere different application related problems. Several authors, considering that the current VAT grouping regime available in the EU is purely national, suggested introduction of pan-EU VAT grouping. At the same time the authors, however, admitted that EU's previous experience shows it being unlikely for the MS to agree on the pan-EU grouping in the nearest future. ${ }^{158}$ In the context of tackling the undesired channelling of acquisitions of services through the establishments located in the other MS or third countries, it is thus important to answer which regime would be efficient enough but, at the same time, would not require eminent changes to the VAT Directive.

Thus, first of all it should be said that although at first glance the current VAT grouping regime available under Article 11 of the VAT Directive does not provide for crossborder VAT grouping, ambiguity on the meaning of terms 'persons' and 'established' contained in the said Article resulted in creation of rather different national systems as regards the cross-border effects. ${ }^{159}$ Some of the MS, in particular the Netherlands, Finland and the UK, allow the VAT groups to include head offices established abroad and having FEs in the respective countries ${ }^{160}$. In addition, the UK and Germany allow

\footnotetext{
157 There are suggestions to treat each member of the cross-border VAT group as a separate taxable person as regards transactions with third parties and only the input VAT deduction to be based on the worldwide pro-rata ratio, see Ruud Zuidgeest, 'Cross-border VAT Grouping' [2010] January/February International VAT Monitor, 30. On the one hand, such a regime, which would follow to some extent the Australian practice, would not eliminate the encouragement for businesses to channel acquisitions through the establishments located in the jurisdictions providing a more favourable tax treatment of the respective supplies. On the other hand, if the VAT group acted as a single taxable person with respect to its supplies and acquisitions, businesses would tend to choose jurisdiction in which the group should be registered and representative member should be located depending on benevolence of taxation rules relevant for respective business. The undesired effects of the latter aspect could, however, be mitigated by clear rules on how the representative member of the group (and thus jurisdiction in which the group should be registered) should be determined based on the corporate structure and financial, economic and administrative ties between the members.

${ }^{158}$ These analyses were mostly done in the context of whether the territorial restriction of Article 11 of the VAT is in line with the freedom of establishment, see, e.g., Ruud Zuidgeest, 'Cross-border VAT Grouping' (n 157) 25-30, Madeleine Merkx, Establishments in European VAT (n 19) 149-161, Casper Bjerregaard Eskildsen, 'VAT Grouping versus Freedom of Establishment' [2011] Issue 3 EC Tax Review. ${ }^{159}$ Kenneth Vyncke, 'VAT Grouping in the European Union: Purposes, Possibilities and Limitations' [2007] July/August International VAT Monitor, 256.

${ }^{160}$ Ivan Massin and Kenneth Vyncke, 'EC Communication on VAT Grouping: An Attempt to Harmonise or to Restrict the Use of Group Registration' [2009] November/December International VAT Monitor, 460.
} 
inclusion of the overseas FEs of the resident entities to the VAT group. ${ }^{161}$ Respectively, these national regimes can already be used for countering undesired channelling of acquisitions of services for tax saving purposes.

Commission of the EU is, however, of the opinion that the said systems are not in line with the VAT Directive and agrees solely with the inclusion into the VAT group of the primary establishments and the FEs located in the respective MS and not those located outside of that MS even if that results in belonging of the FE and the head office to the separate taxable persons. ${ }^{162} \mathrm{CoJ}$ will have an opportunity to rule on these issues in Skandia case which might result in being of extreme relevance for tackling channelling using VAT grouping. AG Wathelet suggested in his opinion issued on 8 May 2014 to conclude that only the whole entity with all its establishments can join the VAT group, meanwhile the FE alone cannot join the VAT group separately from its head office. ${ }^{163}$

If the $\mathrm{CoJ}$ appraises the AG's opinion, practice of the Netherlands, the UK, Germany and Finland, subservient to tackling channelling of acquisitions, will be endorsed and thus the practice of the EU in tackling the channelling by using the VAT grouping will go one step further even without the amendments to the VAT Directive. ${ }^{164}$ If that will not be the case, other VAT grouping regimes, which would likely require changes to the VAT Directive and thus would be much harder to reach, should be considered. As different pan-EU grouping models have been suggested and analysed by several authors and currently it is important to await the decision of the CoJ in Skandia which will clarify the status quo in the cross-border VAT grouping in the EU VAT, proposed panEU grouping models will not be additionally analysed herein. ${ }^{165}$

\section{Conclusions}

The concept of the FE is extremely important in the field of supply of services as it affects the place of taxation and VAT accounting obligations. Despite this relevance, there is a great lack of clarity on various aspects related to the creation and existence of the FE in the EU VAT. Result of this lack of clarity is, firstly, rather different practices of the MS and, secondly, legal uncertainty for the taxpayers who cannot be aware of their VAT obligations. Furthermore, some of the existing vague rules create loopholes from which taxable persons benefit by creating tax saving schemes enabling to reach either double non-taxation of supplies or other tax advantages such as the positive effects to cash flows due to the application of the reverse charge or reduction of

\footnotetext{
${ }^{161}$ Andrea Parolini, Carlos Bechara, Mariken van Hilten, Des Kruger, Rebecca Millar and Greg Sinfield, 'VAT and Group Companies' (n 145) 358, n. 6; PricewaterhouseCoopers Study to Increase the Understanding of the Economic Effects of the VAT Exemption for Financial and Insurance Services, Final Report to the European Commission of 2 November 2006, para. 84; Ivan Massin and Kenneth Vyncke, 'EC Communication on VAT Grouping: An Attempt to Harmonise or to Restrict the use of Group Registration' (n 160) 460.

${ }^{162}$ Communication from the Commission to the Council and the European Parliament on the VAT Group option provided for in Article 11 of Council Directive 2006/112/EC on the common system of value added tax $\operatorname{COM}(2009) 325$ final of 2 July 2009, 8.

${ }^{163}$ Opinion of AG Wathelet in Skandia, C-7/13, EU:C:2014:311, para. 56.

${ }^{164}$ It must, however, be noted that the best result could be achieved only if the VAT grouping regime having cross-border effects is compulsory at the level of both, the MS and the taxable persons. Otherwise, VAT grouping will be itself used in various artificial VAT saving schemes as it is being done currently. This, however, would require changes to the VAT Directive to be made.

${ }^{165}$ See to that effect Ruud Zuidgeest, 'Cross border VAT Grouping' (n 157); PricewaterhouseCoopers Study to Increase the Understanding of the Economic Effects of the VAT Exemption for Financial and Insurance Services, Final Report to the European Commission of 2 November 2006 (n 161).
} 
amounts of non-deductible input VAT. The same loopholes in certain situations are the reason of double taxation. This infringes the principle of fiscal neutrality.

As the purpose of the thesis requires, the preferred treatment of the $\mathrm{FE}$ is discussed herein. It is contended that the passive FE cannot exist separately from the active FE and, respectively, that the FE can only exist for the purposes of both Article 44 and 45 of the VAT Directive where the establishment is engaged in the economic activities in the host MS. The FE is created where there are human and/or technical resources in the host MS that are controlled by the head office and are used to perform the functions forming the core of a particular supply. In any case the FE cannot be created before the certain time threshold is exceeded. Responsibility for the determination of whether the FE is created should fall on the person whose FE is under the examination. Problems related to the attribution of the supplies to the establishments of the customer and channelling of the acquisitions through the foreign establishments should be mitigated by reducing attribution rules and using the rule of internal supply and/or the compulsory VAT grouping having cross-border effects.

Although the described treatment as regards the creation of the FE differs from the current practice in many of the MS, its implementation requires no changes to the VAT Directive or the Implementing Regulation. Due to the very abstract nature of the legislative provisions, the preferred treatment can be reached through the interpretation thereof using the teleological and contextual methods of interpretation. Support of the preferred treatment can be found in the CoJ's practice and scholars' opinions as well. It cannot, however, be denied that additional input of the $\mathrm{CoJ}$ in forming the unanimous interpretation and application is much desired. This would be the most effective way to reach the implementation of the preferred treatment as it is otherwise hard to expect the practice of the MS to change to the same direction at the same time.

Implementation of the suggestions related to the reduction of the burden of the supplier in determining the establishment of the customer to which the service is being supplied, as well as suggestions related to countering artificial channelling of acquisitions through the use of the internal supply rule and the cross-border VAT grouping would require some changes to the VAT Directive and the Implementing Regulation to be made. However, as they would not only provide legal certainty to the taxpayers but also protect fiscal interests of the MS by returning the taxation of the supplies to the MS where the establishment actually using the service is located, it should be in the great interest of the MS to agree on the respective changes. 


\section{Summary}

The concept of the FE is relevant in the EU VAT from the two main perspectives as regards the cross-border supplies of services: entitlement of the MS to tax the supply and distribution of VAT accounting obligations between the supplier and the customer. This influences VAT burden and cash flows of both the parties to the supply and the state in which the supply is subject to VAT.

The concept is, however, far from being clear as definitions provided in the legislation are rather vague and explanations provided by the CoJ are very casuistic and do not represent the rules of the general nature. This creates a field for manipulations for both the taxpayers and the tax administrators. Respectively, the purpose of the thesis is twofold: first, to find the preferred treatment of the FE in the EU VAT stemming from the interpretation of the current legislative provisions and the ECJ's practice, and, second, to suggest the mechanisms for mitigation of the negative effects of taxable persons' manipulations made by channelling acquisitions through the foreign establishments.

Following the Introduction, the second section of the thesis provides a background for the further discussion as it contains the analysis of the link between the principle of taxation at the place of the actual consumption and the secondary reference to the FE in the general place of supply rules for services. In the third section of the thesis, creation of the active FE and attribution of supplies thereto is discussed. It is concluded that the active FE can only exist where the necessary human and/or technical resources are present in the foreign jurisdiction for a period longer than the set threshold and they are actually used in performing the core functions inherent in particular supplies. In the fourth section, the impossibility of the independent existence of the passive FE is discussed. In addition, it is described how the acquisitions of services have to be attributed to the customer's FE and how the taxable persons can manipulate the place of supply and VAT accounting obligations using the foreign FEs. Furthermore, it is suggested that attribution rules should be minimised and the internal supply rule and/or cross-border VAT grouping should be used to minimise the negative effects of channelling of the acquisitions through the foreign establishments. 


\section{Bibliography}

EU legislation:

1) Council Implementing Regulation No 282/2011 of 15 March 2011 laying down implementing measures for Directive 2006/112/EC on the common system of value added tax, [2011] OJ L 77/1

2) Council Directive 2008/8/EC of 12 February 2008 amending Directive 2006/112/EC as regards the place of supply of services, [2008] OJ L 44/11

3) Council Directive 2006/112/EC of 28 November 2006 on the common system of value added tax, [2006] OJ L 347/1

4) Council Regulation (EC) No 2157/2001 of 8 October 2001 on the Statute of European Company (SE), [2001] OJ L 294/1

5) Thirteenth Council Directive 86/560/EEC of 17 November 1986 on the harmonization of the laws of the Member States relating to turnover taxes Arrangements for the refund of value added tax to taxable persons not established in Community territory, [1986] OJ L 326/40

Other EU documents:

1) VAT Committee Working Paper No 791 Concerning the Application of EU VAT Provisions of 15 January 2014

2) Communication from the Commission to the Council and the European Parliament on the VAT Group option provided for in Article 11 of Council Directive 2006/112/EC on the common system of value added tax $\operatorname{COM}(2009) 325$ final of 2 July 2009

3) Guidelines adopted at the $86^{\text {th }}$ meeting of the VAT Committee on 18-19 March 2009

4) EC Consultation Paper VAT - The Place of Supply of Services to Non-Taxable Persons, 2005

5) European Commission MEMO/01/314 of 8 October 2001 on frequently asked questions about the SE

CoJ case law:

1) Judgment in Rompelman, 268/83, EU:C:1985:74

2) Judgment in Berkholz, 168/84, EU:C:1985:299

3) Judgment in Factortame II, C-221/89, EU:C:1991:320

4) Judgment in Renate Enkler, C-230/94, EU:C:1996:352

5) Judgment in Faaborg, C-231/94, EU:C:1996:184

6) Judgment in Inzo, C-110/94, EU:C:1996:67

7) Judgment in $A R O$ Lease, C-190/95, EU:C:1997:374

8) Judgment in $D F D S$, C-260/95, EU:C:1997:77

9) Judgment in Lease Plan Luxembourg, C-390/96, EU:C:1998:206

10) Judgment in Midland Bank, C-98/98, EU:C:2000:300

11) Judgment in Halifax, C-255/02, EU:C:2006:121

12) Opinion of AG Maduro in $R A L, \mathrm{C}-452 / 03, \mathrm{EU}: \mathrm{C}: 2005: 65$

13) Judgment in $R A L, \mathrm{C}-452 / 03$, EU:C:2006:289

14) Judgment in FCE, C-210/04, EU:C:2006:196

15) Judgment in Part Service, C-425/06, EU:C:2008:108

16) Judgment in RBS Deutschland, C-277/09, EU:C:2010:810 
17) Judgment in Daimler and Widex, Joined Cases C-318/11 and C-319/11, EU:C:2012:666

18) Judgment in PPG Holding, C-26/12, EU:C:2013:526

19) Judgment in $A E S, \mathrm{C}-124 / 12$, EU:C:2013:488

20) Judgment in Tulica and Plavosin, Joined Cases C-247/12 and C-250/12, EU:C:2013:256

21) Judgment in Le Credit Lyonnais, C-565/12, EU:C:2014:190

22) Opinion of AG Wathelet in Skandia, C-7/13, EU:C:2014:311

23) Opinion of AG Kokott in Welmory, C-605/12, EU:C:2014:366

Books:

1) Merkx M., Establishments in European VAT (Kluwer Law International 2013)

2) Terra B. and Kajus J., A Guide to the European VAT Directives, Volume 1, Introduction to European VAT (IBFD 2013)

3) Terra B., The VAT Package and Anti-tax Fraud Measures (Lund University School of Economic and Management 2009)

4) Terra B. And Wattel P., European Tax Law (Kluwer Law International 2012)

Doctrinal Articles:

1) Amand C., 'Cross-Border Entities and EU VAT: A Contradictory Concept?' [2010] January/February International VAT Monitor, 20-24.

2) Amand C., 'VAT Grouping, FCE Bank and Force of Attraction - The Internal Market is Leaking' [2007] July/August International VAT Monitor, 237-249

3) Charlet A. and Holmes D., 'Determining the Place of Taxation of Transactions under VAT/GST: Can Transfer Principles Help?' [2010] November/December International VAT Monitor, 431-438.

4) De Broe L., 'Cross-border leasing of cars into Belgium: issues of VAT and the freedom to provide services - analysis of and comments on the European Court's holding in Aro Lease' [1997] 1997/4 EC Tax Review, 215-226

5) Doesum A., Kesteren H. and Norden G. 'The Internal Market and VAT: intragroup transactions of branches, subsidiaries and VAT groups' [2007] 2007-1 EC Tax Review, 34-43

6) Doesum A., Kesteren H., Norden G. and Reiniers I., 'The New Rules on the Place of Supply of Services in European VAT' [2008] 2008-2 EC Tax Review, 78-89

7) Ecker T., 'Place of Effective Use and Enjoyment of Services - EU History Repeats Itself' [2012] November/December International VAT Monitor, 407410.

8) Eskildsen C., 'Pro Rata Deduction by Entities Established in Several VAT Jurisdictions' [2012] January/February International VAT Monitor, 27-30

9) Eskildsen C., 'VAT Grouping versus Freedom of Establishment' [2011] Issue 3 EC Tax review, 114-120

10) Gorazda M. and Benito D., 'Destination Principle in Intra-Community Services and the "Fixed Establishment" in the VAT. A Comparative Study of Polish and Spanish Law' [2014] Volume 42, Issue 2 Intertax, 122-135

11) Glauser P., 'Head Office/Branch Relationship from the Perspective of Swiss VAT' [2010] January/February International VAT Monitor, 31-35 
12) Iavagnilio M., 'Concepts of Permanent and Fixed Establishments under Italian Law - the Philip Morris Case' [2002] November/December VAT Monitor, 470475

13) Lejeune I., Cortvriend E. and Accorsi D., 'Implementing Measures Relating to EU Place-of-Supply Rules: Are Business Issues Solved and Is Certainty Provided?' [2011] May/June International VAT Monitor, 144-152

14) Lenoir N., 'The Societas Europea (SE) in Europe. A promising start and an option with good prospects' [2008] March, Volume 5, Issue 1 Utrecht Law Review, 13-21

15) Massin I. and Vyncke K., 'EC Communication on VAT Grouping: An Attempt to Harmonise or to Restrict the Use of Group Registration' [2009] November/December International VAT Monitor, 454-461

16) Merkx M., 'Should EU VAT Apply the Recharge Method in the Place of Supply Rules for B2B Services?' [2013] 2013-06 EC Tax Review, 282-288

17) Merkx M., 'Fixed Establishment and VAT Liabilities under EU VAT - Between Delusion and Reality' [2012] January/February International VAT Monitor, 2226

18) Parolini A., Bechara C., Hilten M., Kruger D., Millar R. and Sinfield G., 'VAT and Group Companies' [2011] June Bulletin for International Taxation, 349-362

19) Pistone P., 'Fixed Establishment and Permanet Establishment', [1999] May/June VAT Monitor, 101-106

20) Schaffner J., 'The Teritorial Link as a Condition to Create a Permanent Establishment' [2013] Volume 41, Issue 12 Intertax, 638-651

21) Schilling P. and Hogan D., 'Intervention - a Problematic New Concept in EU VAT Law' [2010] May/June International VAT Monitor, 187-193

22) Swinkels J., 'The Phenomenon of VAT Groups under EU Law and Their VATSaving Aspects' [2010] January/February International VAT Monitor, 36-42

23) Swinkels J., 'Scope of the Self-Supply Rule under EU VAT' [2008] May/June International VAT Monitor, 175-181

24) Swinkels J. 'Fixed Establishments and VAT-Saving Schemes' [2006] November/December International VAT Monitor, 415-423

25) Vyncke K., 'VAT Grouping in the European Union: Purposes, Possibilities and Limitations' [2007] July/August International VAT Monitor, 250-261

26) Zuidgeest R., 'Cross-border VAT Grouping' [2010] January/February International VAT Monitor, 25-30

National legal documents:

1) Lietuvos Respublikos pridètinès vertès mokesčio įstatymo 13 straipsnio apibendrintas komentaras (Commentary to Article 13 of the Law on VAT of the Republic of Lithuania) $<$ http://mic.vmi.lt/documentpublicone.do?id=100013013 $\underline{3}>$

OECD documents:

1) Public Discussion Draft on BEPS Action 1 of 24 March 2014

2) Plan on Base Erosion and Profit Shifting of the OECD of 19 July 2013

3) VAT/GST Guidelines of the OECD $<$ http://www.oecd.org/ctp/consumption/ConsolidatedGuidelines20130131.pdf $>$

4) OECD Commentary to the Model Convention on Income and on Capital (OECD 2010) 
Websites:

1) Consultations of the VAT committee up to 20 February 2014 $<$ http://ec.europa.eu/taxation_customs/resources/documents/taxation/vat/key do cuments/vat committee/consultations vat committee en.pdf $>$

2) George Reisman's blog on Economics, Politics, Society and Culture $<$ http://georgereisman.com/blogWP/?tag=productive-expenditure $>$

3) Bloomerg BNA news $<$ http://www.bna.com/spanish-court-imposes$\underline{\mathrm{n} 17179871765 />}$

4) $\mathrm{HM}$ Revenue and Customs consultation $<\underline{\text { http://www.hmr.gov.uk/manuals/vatpossmanual/vatposs05100.htm }>}$

Other sources:

1) PricewaterhouseCoopers Study to Increase the Understanding of the Economic Effects of the VAT Exemption for Financial and Insurance Services, Final Report to the European Commission of 2 November 2006

2) PricewaterhouseCoopers report on the judgment of the CoJ in the Case C-565/12 Le Credit Lyonnais < http://www.out-law.com/articles/2013/september/creditlyonnais-decision-shows-deficiencies-in-eus-vat-treatment-of-internationalbranches-says-expert/> 